\title{
RUSYA FEDERASYONU CEZA HUKUKUNDA SUÇA TEŞEBBÜS*
}

DOI: https://doi.org/10.33717/deuhfd.787670

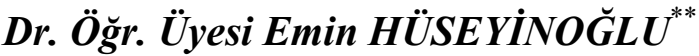

$\ddot{O} \mathbf{z}$

Rusya Federasyonu ceza hukukunda suça teşebbüsün sadece doğrudan kastla mümkün olabileceği kabul edilmektedir.

Rusya Federasyonu ceza hukukunda işlenemez suça teşebbüs de cezalandırılmaktadır. Örneğin öldürmek amacıyla bir kimseye zehir zannederek tebeşir tozu vermek veya canl zannederek cesede ateş etmek filleri teşebbüs hükümlerine göre cezalandırllmaktadır. Bununla birlikte; beddua, lanetleme, ölüm büyüsü yapma gibi sosyal açıdan tehlikeli olmayan hareketler Rusya Federasyonu Ceza Kanunu'nun 14/2. maddesi kapsamında değerlendirilmekte ve cezalandırilmamaktadır.

Rusya Federasyonu Ceza Kanunu’nda gönüllü vazgeçme, "suça hazırlık hareketlerinin veya doğrudan doğruya suçun işlenmesine yönelmiş hareketlerin durdurulması" şeklinde düzenlenmiştir.

Rusya Federasyonu Ceza Kanunu'nda suç öncesi ve suç sonrası etkin pişmanlık halleri düzenlenmiştir. Suç öncesi etkin pişmanlık, genel cezayı hafifletici neden olarak düzenlenmiştir. Suç sonrası etkin pişmanlık ise bazı durumlarda cezayı ortadan kaldıran neden olarak düzenlenmiştir.

\section{Anahtar Kelimeler}

Rusya Federasyonu, Ceza Hukuku, Suça Teşebbüs, Işslenemez Suç, Gönüllü Vazgeçme

Bu çalışma, "Hüseynov, Emin: Rusya Federasyonu Ceza Hukukunda Suça Teşebbüs, Ankara Üniversitesi, Sosyal Bilimler Enstitüsü Doktora Tezi, Ankara 2011" isimli doktora tezinden üretilmiştir.

** Karabük Üniversitesi İktisadi ve İdari Bilimler Fakültesi, Siyaset Bilimi ve Kamu Yönetimi Bölümü Öğretim Üyesi (e-posta: eminhuseyinoglu@karabuk.edu.tr) ORCID: https://orcid.org/0000-0002-4196-2295. (Makalenin Geliş Tarihi: 15.05.2020) (Makale Gönderilme Tarihi: 22.05.2020/Makale Kabul Tarihi: 30.06.2020) 


\title{
CRIMINAL ATTEMPT IN THE CRIMINAL LAW OF THE RUSSIAN FEDERATION
}

\begin{abstract}
It is accepted in the criminal code of Russian Federation that the criminal attempt is possible only with the direct intention.

The criminal attempt for the crime which cannot be committed is also penalized in accordance with the criminal code of Russian Federation. For instance, to give chalk powder to somebody to kill by assuming that the chalk powder is the posion or to shoot a dead body to kill by assuming that person is alive are penalized in accordance with the provisions for the criminal attempt. However, the actions which are not dangereous for social life such as curse, malediction or black magic are considered and penalized in the scope of the Article 14/2 of the Criminal Code of Russian Federation.

The voluntary waiver is regulated as the 'stop the actions for preparation for crime or stop the actions aimed to commit the crime direct' in the Criminal Code of Russian Federation.

The effective repentance conditions before and after the crime are stated in the Criminal Code of Russian Federation. The effective repentance before committing the crime is considered as the matter in mitigation for the general punishment. The effective repentance after committing the crime is considered as the reason to revoke the punishment in some cases.
\end{abstract}

\section{Keywords}

Russian Federation, Criminal Law, Criminal Attempt, factual impossibility, Voluntary Waiver 


\section{GíRiş}

Suça teşebbüs, ceza hukukunda suç teorisinin en önemli ve üzerinde en çok tartışılan kurumlarından biridir. Suça teşebbüsün hukuki niteliği, cezalandırılma nedeni, icra hareketlerinin ne zaman başlamış sayılacağı, hazırlık hareketlerinin ve işlenemez suç (elverişsiz teşebbüs) hallerinin cezalandırılıp cezalandırılmayacağı, suça teşebbüsün cezasının ne olacağı konularında değişik teoriler ileri sürülmüş, farklı ülkeler farklı sistemleri kabul etmişlerdir.

Suça teşebbüs konusunda Rusya Federasyonu Ceza Kanunu (RFCK) ve Türk Ceza Kanunu (TCK) birbirinden farklı sistemleri kabul etmiş ve farklı hükümlere yer vermişlerdir. Örneğin işlenemez suç halleri ve kural olarak hazırlık hareketleri Türk ceza hukukunda cezalandırılmazken, Rusya Federasyonu ceza hukukunda işlenemez suç halleri ve hazırlık hareketlerinin cezalandırıldığ 1 görülmektedir.

$\mathrm{Bu}$ çalışmanın konusunu "Rusya Federasyonu Ceza Hukukunda Suça Teşebbüs" oluşturmaktadır. Çalışmanın Türk okuruna yönelik olması sebebiyle, çalışmada ayrıca RFCK'da yer alan teşebbüs hükümleri ile TCK'da yer alan teşebbüs hükümleri arasında karşılaştırmalar yapılmaktadır.

\section{SUÇA TEŞEBBÜSÜN TEORİK TEMELI}

\section{A. Suç Yolu}

Somut oluşumu yönünden dikkate alındığında suçun, kural olarak, çeşitli aşamalardan geçerek gerçekleştiği görülür. Suçun oluşuncaya kadar geçilen bu aşamaların bütününe "suç yolu" denilir ${ }^{1}$. Bu yol düşünce, hazırlık hareketleri, icra hareketleri ve suçun tamamlanması aşamalarına ayrılabilir² .

Düşünce aşaması failin psişiğinde oluşur ve suç işleme kararında son şeklini alır ${ }^{3}$. Bu aşamada, suç failin zihninde gerçekleşmektedir, henüz dış dünyaya yansımamıştır ${ }^{4}$. Türk ceza hukukunda olduğu gibi Rusya Federasyonu ceza hukukunda düşünce aşaması cezalandırılmamaktadır.

Suç işlemeye karar veren kişi, suç işlemek için araç veya alet elde etme, ortak arama, başkalarıyla anlaşma gibi suçun işlenmesine ortam yaratan bazı hareketleri gerçekleştirir. Bu tür hareketler, hazırlık hareketleri olarak

Toroslu, Nevzat: Ceza Hukuku, Genel Kisım, 13. Bask1, Ankara 2009, s. 248.

Piontkovskiy, Andrey: Kurs Sovetskogo Ugolovnogo Prava (Sovyet Ceza Hukuku Dersleri), Tom 2 (Cilt 2), Prestupleniye (Suç), Moskva 1970, s. 403.

Toroslu, s. 248.

Hafızoğulları, Zeki/Özen, Muharrem: Türk Ceza Hukuku, Genel Hükümler, 9. Baskı, Ankara 2016, s. 305. 
değerlendirilir. Türk ceza hukukunda hazırlık hareketleri kural olarak cezalandırılmamaktadır. Rusya Federasyonu ceza hukukunda ise hafif ve orta dereceli suçlara hazırlık cezalandırılmamakla birlikte, ağır ve nitelikli ağır suçlara hazırlık cezalandırılmaktadır 5 .

Hazırlık hareketlerinin sonra erip icra hareketlerinin başlanmasıyla birlikte teşebbüs sürecine girilmiş olur. TCK ve RFCK'da failin "doğrudan doğruya" suçun icrasına başlama anı, icra hareketi olarak kabul edilmiştir. $\mathrm{Bu}$ şekilde icra hareketlerine başlayan fail, elinde olmayan nedenlerden dolayı suçu tamamlayamazsa, suça teşebbüs söz konusu olur.

Suçun varlığı için gerekli olan unsurların gerçekleşmesiyle birlikte ise suçun tamamlanma anı gerçekleşmiş olur'. RFCK'nın 29. maddesinde tamamlanmış ve tamamlanmamış suçun tanımı yapılmıştır. Buna göre; " 1 . Kişinin işlediği fiilde bu Kanunda öngörülen suç tipinin bütün unsurları mevcutsa, suç tamamlanmış sayllır. 2. Suça hazırlı ve suça teşebbüs tamamlanmamış suç sayılır".

\section{B. Suça Teşebbüsün Hukuki Niteliği}

Kanunilik ilkesine göre, faile ancak suçun kanuni tanımında yer alan bütün unsurları gerçekleştirmesi halinde ceza verilebilir. Oysa suça teşebbüste, suç tamamlanmış değildir. Örneğin kasten öldürme suçunun kanuni tanımında "bir kimseyi kasten öldüren kişi, cezalandırılır" denilmektedir. Bir kimseye doğru ateşlenen mermilerin boşa gitmesi durumunda kasten öldürme suçunun tamamlandığı söylenemez ${ }^{7}$.

Ancak, suçla korunmak istenen hukuki değerlerin, tamamlanmamış olmasına karşın belirli niteliğe sahip eylemlere karşı da korunması gerekmektedir. Bu gereksinimden hareketle kanun koyucular suça yönelik olan tamamlanmamış eylemlerin de cezalandırılacağına ilişkin özel düzenleme-

17.06.2019 tarih ve N146-FZ sayılı Kanunla değiştirilen RFCK'nın 15. maddesine göre; üst sınırı 3 seneye kadar hapis cezasını gerektiren kasıtlı ve taksirli suçlar, hafif suç sayılır. Üst sınırı 5 seneye kadar hapis cezasını gerektiren kasıtlı suçlar ile üst sınırı 10 seneye kadar hapis cezasını gerektiren taksirli suçlar, orta dereceli suç sayılır. Üst sınırı 10 seneye kadar hapis cezasını gerektiren kasıtll suçlar ile üst sınırı 15 seneye kadar hapis cezasını gerektiren taksirli suçlar, ağır suç sayılır. Üst sınırı 10 seneden fazla hapis cezasını veya daha ağır cezayı gerektiren kasıtlı suçlar ise nitelikli ağır suç sayılır. Dolayısıyla Rusya federasyonu ceza hukukunda üst sınırı 5 seneden fazla hapis cezasını gerektiren kasıtlı suçlara hazırlık cezalandırılmakta iken, üst sınırı 5 sene ve daha az hapis cezasını gerektiren kasıtlı suçlara hazırlık ise cezalandırılmamaktadır.

İpekçioğlu, Pervin Aksoy: Türk Ceza Hukukunda Suça Teşebbüs, Ankara 2009, s. 22.

Dönmezer, Sulhi/Erman, Sahir: Nazari ve Tatbiki Ceza Hukuku, Genel Kısım, Cilt 1, İstanbul 1987, s. 405; Sözüer, Adem: Suça Teșebbüs, İstanbul 1994, s. 46. 
lere gitmiştir ${ }^{8}$. Ceza kanunlarında suça teşebbüsün cezalandırılmasına yönelik hükümler bulunmasaydı, suça teşebbüs cezalandırılamazd ${ }^{9}$.

Manevi unsur açısından suça teşebbüs, tamamlanmış suçtan farklı değildir. Teşebbüs halinde kalan suç sadece maddi yönden eksik kalmıştır, çünkü suçun kanuni tanımındaki eylem ancak kısmen gerçekleşmiştir ${ }^{10}$.

Bir görüşe göre teşebbüs, tamamlanmış suçun bir parçası olmayıp, kendine özgü bir özerkliğe sahiptir. Teşebbüs hükümlerinin genel kısımda düzenlenmesinin nedeni, farklı suç tiplerine ilişkin olmasıdır. Teşebbüsün diğer suçlarla bağlantısını oluşturan esas nokta niyet ve sonuçtur. Ancak, teşebbüs tamamlanmış suç gibi, kendine özgü niteliğe sahip bağımsız bir suç oluşturmaktadır. Teşebbüse ilişkin hükümler, tamamlayıcı veya hafifletici niteliğe sahip değildirler. Teşebbüs halinde kalan suçun cezalandırılabilmesi için suçun tamamlanmış şeklinin tanımlandığı hükme başvurmak gerekli değildir ${ }^{11}$.

Bir başka görüşe göre teşebbüs, tamamlanmış suçun hafifletici nedenini oluşturmaktadır. Tamamlanmış suçta isnat edilen fiil ile teşebbüste isnat edilen fiil aynı olmakla birlikte, teşebbüs fiilinde bir azlık vardır. Bu nedenle teşebbüsün daha az ceza ile cezalandırılması gerekir ${ }^{12}$.

Bizim de katıldığımız ve doktrinde hakim olan görüşe göre ise teşebbüs bağımsız bir suç olmadığı gibi hafifletici neden de değildir. Teşebbüse ilişkin hükümler kendi başlarına bir anlam ifade etmemektedirler ${ }^{13}$. Bu hükümler ancak tamamlanmış suçun düzenlendiği norma bağlı olarak uygulanabilir bir nitelik gösterirler. Ceza kanunlarında başlı başına bir teşebbüs suçu bulunmamaktadır. Teşebbüs hükümleri suç tipinde gösterilen fiilin tamamlanmadığı olaylarda, failin hangi koşullar altında cezalandırılacağını açıklamaktadır ${ }^{14}$. Teşebbüs derecesinde kalan bir suç tipi, tamamlanmış suça ilişkin hüküm ile teşebbüse ilişkin hüküm olmak üzere iki normun bir araya

8 İçel, Kayıhan/Evik, A. Hakan: Ceza Hukuku, Genel Hükümler, 2. Kitap, 4. Bası, İstanbul 2007, s. 236.

9 Kuznesova, Ninel/Tyajkova, İrina (Ed.): Kurs Ugolovnogo Prava (Ceza Hukuku Dersleri), Obşaya Çast (Genel Kısım), Uçeniya o Prestuplenii (Suç Hakkında), Tom 1 (Cilt 1), Moskva 2002, s. 366.

10 Toroslu, s. 252; Erem, Faruk/Danıșman, Ahmet/Artuk, Mehmet Emin: Ümanist Doktrin Açısından Türk Ceza Hukuku, Genel Hükümler, Ankara 1997, s. 293-294; Hafızoğulları/Özen, s. 307.

Bkz. İpekçioğlu, s. 32.

Bkz. Soyaslan, Doğan: Teşebbüs Suçu, Ankara 1994, s. 55.

Soyaslan, s. 52.

Sözüer, s. 46. 
gelmesinden ortaya çıkmaktadır. Teşebbüse ilişkin hüküm, tamamlanmış suça ilişkin normları tamamlayıcı özelliğe sahip olup, bu normların cezalandırılabilme alanını genişletmektedir ${ }^{15}$. Teşebbüs, tamamlanmış suçun hafifletici nedeni değildir. Çünkü suça etki eden nedenlerin, suçun tipik şekline oranla daima bir fazlalığg ifade etmelerine karşın, teşebbüs bir azlığı ifade etmektedir ${ }^{16}$.

Cezayı hafifletici nedenleri düzenleyen RFCK'nın 61. maddesine bakıldığında da bunlar arasında suça teşebbüsün yer almadığı görülmektedir. Suça teşebbüs ve suça hazırlık halinde hükmedilecek ceza, RFCK'nın 66. maddesinde "Tamamlanmamış suçtan dolayı belirlenecek ceza" başlığı altında düzenlenmiştir. Bu yüzden suça teşebbüs ve suça hazırlık durumunda tamamlanmış suça oranla daha az ceza verilmesine rağmen, suça teşebbüs ve suça hazırlık birer cezayı hafifletici neden değildir.

\section{Suça Teşebbüsün Cezalandırılma Nedenini Açıklayan Teoriler}

\section{Objektif Teori}

Objektif teoriye göre, suça teşebbüsün cezalandırılma nedeni suç tipiyle korunan konunun tehlikeye sokulmasıdır ${ }^{17}$. Tamamlanmış suçta, suçla korunmak istenen hukuki değerler ihlal edilirken, teşebbüste bu ihlal hukuki değerlerin tehlikeye sokulması şeklinde gerçekleşmektedir ${ }^{18}$. İcra hareketlerine başlanmadığı sürece suç tipiyle korunan hukuki değer için bir tehlike meydana gelmeyeceğinden, bu teoriye göre hazırlık hareketlerine ceza verilmez ${ }^{19}$.

$\mathrm{Bu}$ teoride suçlu irade dikkate alınmadığ 1 için suçun objektif olarak gerçekleşmesi tehlikesinin doğmadığ $\breve{g}_{1}$ hallerde faile ceza verilmez. ${ }^{20}$. Dolayısıyla bu teoriye göre, mutlak elverişsiz teşebbüs (işlenemez suç) olarak adlandırılan eylemlere ceza verilmez ${ }^{21}$.

Objektif teori, suça teşebbüs halinde mutlak ceza indirim sistemini öngörmektedir ${ }^{22}$. Yine bu teoriye göre, icra hareketlerinin tamamlanmaması

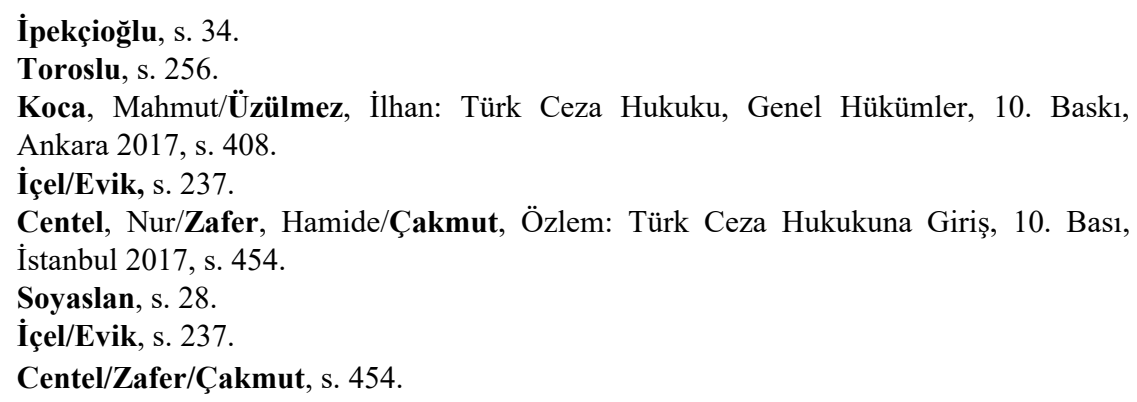


(eksik teşebbüs) ile icra hareketlerinin tamamlanmasını (tam teşebbüs) ${ }^{23}$ farklı cezalandırmak gerekir. Çünkü suçla korunmak istenen hukuki değerin maruz kaldığ tehlike yakın veya uzak olabilir ${ }^{24}$.

Objektif teoriye göre, gönüllü vazgeçme ile suç öncesi etkin pişmanlığı da birbirinden ayırmak gerekir. Her ikisinde de vazgeçilmiş olsa bile, gönüllü vazgeçmede faile ceza verilmemeli, suç öncesi etkin pişmanlıkta ise faile ceza verilmelidir ${ }^{25}$. Yani icra hareketlerini tamamlamaktan vazgeçen kişi, teşebbüsten cezalandırılmayacak; buna karşılık, icra hareketlerini tamamladıktan sonra çaba göstererek neticenin gerçekleşmesini önleyen kişi, teşebbüs hükümlerine göre cezalandırılacaktır.

\section{Sübjektif Teori}

Sübjektif teori, suça teşebbüsün cezalandırılma nedenini etkin ve hukukla çatışan iradeye dayandırmaktadır ${ }^{26}$. Bu teoriye göre, suça teşebbüsün cezalandırılma nedeni, tehlikeli kişiliğini ortaya koyan failin suç işlemeye yönelik dış dünyaya yansıttığı iradedir. Objektif teorinin aksine, bu teori sübjektif tehlikeliliği cezalandırma nedeni saymaktadır ${ }^{27}$. Bu nedenle, elverişsiz teşebbüs hallerinde de failin cezalandırılması gerekir ve ayrıca eksiktam teşebbüs ayrımına gerek yoktur ${ }^{28}$.

Suçla korunan hukuki değerin tehlikeye sokulmasını değil, failinin dışa yansıyan iradesini esas alması nedeniyle, bu teori hazırlık hareketlerine de ceza verilmesi sonucunu doğurarak, cezalandırma alanını genişletir ${ }^{29}$.

Sübjektif teori, suça teşebbüs halinde mutlak ceza indirim sistemi yerine, takdire bağlı indirim sistemini öngörmektedir ${ }^{30}$.

Sübjektif teoriye göre gönüllü vazgeçme ile suç öncesi etkin pişmanlık arasında bir fark gözetilmemelidir. Çünkü her iki durumda da fail suçun icrasına başladıktan sonra kendiliğinden suçtan vazgeçmektedir ${ }^{31}$.

765 sayılı eski TCK'da bulunan eksik-tam teşebbüs ayırımı, yürürlükteki TCK'da bulunmamaktadır. Doktrinde bulunmakla birlikte, eksik - tam teşebbüs ayırımı RFCK'da da bulunmamaktadır.

24

Soyaslan, s. 28-29.

Soyaslan, s. 29.

Koca/Üzülmez, s. 409.

Bkz. İçel/Evik, s. 237.

Centel/Zafer/Çakmut, s. 454.

Centel/Zafer/Çakmut, s. 454.

Centel/Zafer/Çakmut, s. 454.

Soyaslan, s. 31 . 


\section{Karma Teoriler}

Sübjektif teorinin cezalandırma sınırını aşırı bir şekilde genişletmesi, failin suç işleme iradesini esas alan, ancak bunu objektif ölçülerle tamamlayan karma teorilerin oluşmasına yol açmıştır ${ }^{32}$.

Bunlardan etki teorisine göre; suça teşebbüsün cezalandırılma nedeni, hem failin suç işleme iradesini açığa vurması, hem de hareketin hukuk düzeni açısından olumsuz bir etki yaratmış, toplumun huzur ve güvenini bozmuş olmasıdır ${ }^{33}$. Teşebbüsün cezai temeli, bir davranış normuna karşı çıkan, başka bir deyişle hukuka düşman iradedir; ancak bir teşebbüs sadece iradenin bir fiille açığa vurulmasının kamu düzenine olan güvenini sarstığ zaman ve hukuki güvenlik ve hukuki barış hissinin olumsuz etkilendiği zaman cezalandırmaya değerdir ${ }^{34}$.

$\mathrm{Bu}$ teoriye göre, hazırlık hareketleri hukuku sarsıcı etkiye sahip olmadıkları veya bu etkiyi çok yüzeysel, geçici olarak doğurdukları için genellikle cezay1 gerektirmemektedir ${ }^{35}$.

Etki teorisi taraftarları, elverişsiz teşebbüs hallerinin kural olarak cezalandırılması gerektiğini savunurlar. Buna göre, hukuki yararın somut olarak tehlikeye sokulmadığı durumlarda, söz konusu yararın koruma alanının rahatsız edilmesiyle ortaya çıkan etki, elverişsiz teşebbüs olarak adlandırılan olayların da cezalandırılmasını gerektirir. Örneğin, failin kendinden habersiz olarak önceden boşaltılmış bir silahla, öldürmek amacıyla ateş etmesi durumunda somut bir tehlike yoktur. Ancak fail bu hareketiyle, insan hayatını koruyan hukuki yararın barış ve güvenlik içindeki konumunu rahatsız etmesinden dolayı cezalandırılmalıdır ${ }^{36}$.

Etki teorisi taraftarları, teșebbüste verilecek ceza bakımından, takdiri bir ceza indirimini önermektedirler ${ }^{37}$.

\section{Türk Ceza Kanunu’nun Benimsediği Teori}

"Suça teşebbüs” başl1klı TCK'nın 35. maddesine göre, "(1) Kişi, işlemeyi kastettiği bir suçu elverişli hareketlerle doğrudan doğruya icraya

32 Öztürk, Bahri/Erdem, Mustafa Ruhan: Uygulamalı Ceza Hukuku ve Güvenlik Tedbirleri Hukuku, Ankara 2015, s. 312.

33 Centel/Zafer/Çakmut, s. 455.

34 Tozman, Önder: Suça Teşebbüs, Ankara Üniversitesi, Sosyal Bilimler Enstitüsü, Doktora Tezi, Ankara 2008, s. 29.

35 Tozman, s. 30.

36 Bkz. Sözüer, s. 113, 136.

37 Bkz. Sözüer, s. 115. 
başlayıp da elinde olmayan nedenlerle tamamlayamaz ise teşebbüsten dolayı sorumlu tutulur. (2) Suça teşebbüs halinde fail, meydana gelen zarar veya tehlikenin ă̆ırlığına göre, ăğrlaştırllmış müebbet hapis cezası yerine onü̧ yıldan yirmi yıla kadar, müebbet hapis cezası yerine dokuz yıldan onbeş yıla kadar hapis cezası ile cezalandırllır. Diğer hallerde verilecek cezanın dörtte birinden dörtte üçüne kadarı indirilir".

Hazırlık hareketlerine ceza verilmiyor olması, teşebbüs için failin elverişli hareketlerle doğrudan doğruya suçun icrasına başlamasının şart olması ve teşebbüste meydana gelen zarar ve tehlikenin ağırlığına göre indirimli ceza öngörülmesi TCK'nın objektif teoriyi benimsediğini göstermektedir ${ }^{38}$.

\section{Rusya Federasyonu Ceza Kanunu'nun Benimsediği Teori}

"Suçu hazırlık ve suça teşebbüs" başl1klı RFCK'nın 30. maddesine göre, "1. Kişinin suçun alet veya araçlarını araması, hazırlaması veya elde etmesi, suç ortağı araması, suç işlemek için anlaşma ya da suç işlemek için kasten farklı ortam yaratma, suç kişinin elinde olmayan nedenlerle tamamlanmamışsa, suça hazırlık sayılır. 2. Sadece ağır ve nitelikli ağır suçlara hazırlık ceza sorumluluğuna sebep olur. 3. Kişinin doğrudan suçun işlenmesine yönelmiş kasitlı hareketleri (hareketsizlik) ${ }^{39}$, suç kişinin elinde olmayan nedenlerle tamamlanmamışsa, suça teşebbüs sayılır".

$\mathrm{Bu}$ düzenleme nedeniyle, RFCK'nın teşebbüsün cezalandırılma nedeni bakımından sübjektif teoriyi benimsediği söylenebilir. Çünkü RFCK'da suça teşebbüsün yanında, hazırlık hareketleri ve işlenemez suç halleri de cezalandırılmaktadır.

Ancak Kanunda bu teorinin objektif ölçütlerle tamamlandığı da söylenebilir. Çünkü RFCK'da suça teşebbüsün tamamlanmış suçtan daha hafif bir ceza ile cezalandırılacağı öngörülmüştür. Yine Kanunda suça hazırlık, suça teşebbüsten ayrı düzenlenmiş ve suça teşebbüsten daha hafif bir ceza ile cezalandırılacağı öngörülmüştür. Ayrıca Kanunda ağır ve nitelikli ağır suçlara hazırlık cezalandırılmakla birlikte, hafif ve orta dereceli suçlara hazırlık cezalandırılmamaktadır. Bunun yanında RFCK'nın 14/2. maddesi nedeniyle, az önemli olması nedeniyle sosyal tehlikeli sayılmayan hazırlık hareketleri de cezalandırılmamaktadır ${ }^{40}$.

38 Koca/Üzülmez, s. 410; Centel/Zafer/Çakmut, s. 455. RFCK'nın 30/3. maddesinde geçen "hareketsizlik" terimi yerine Türk ceza hukukunda daha çok "ihmali davranış" veya "ihmal" gibi terimler kullanılmaktadır.

40

Suçun sosyal tehlikelilik özelliği ve RFCK'nın 14/2. maddesi hakkında ayrıntılı bilgi için bkz. Hüseyinoğlu, Emin: "Suçun Biçimsel ve Maddi Anlayışı Açısından Rusya 


\section{SUÇA TEŞEBBÜSÜN UNSURLARI}

\section{A. Sübjektif (Manevi) Unsur}

Teşebbüs ile tamamlanmış suç arasında manevi unsur bakımından bir fark bulunmamaktadır ${ }^{41}$. Teşebbüste aranan kast $^{42}$, icrasına başlanmış olan suçu teşebbüs derecesinde birakmak kastı olmayıp, söz konusu suçu tamamlamaya yönelik bir kasttır ${ }^{43}$.

Suça teşebbüs, doğrudan kastla işlenen suçlar bakımından mümkündür. Rusya Federasyonu Yüksek Mahkemesi'nin Kasten Öldürme Suçlarına İlişkin Mahkeme Uygulamaları Hakkındaki 27.01.1999 tarih ve 1 No.lu Genel Kurul kararında ${ }^{44}$, kasten öldürme suçuna teşebbüsün sadece doğrudan kastla mümkün olabileceği belirtilmiştir ${ }^{45}$. Bu yüzden uygulamada olas1

Federasyonu Ceza Hukukunda Suç Kavramı”, Ankara Barosu Dergisi, Cilt 76, Sayı 1, 2018, s. 132-139.

\section{Semenderov, Firudin: Cinayet Hüququ, Ümumi Hisse, Bak1 2007, s. 332.}

Rusya Federasyonu Yüksek Mahkemesi’ne göre; “Failin kastının hangi suça yöneldiğinin tespiti sırasında işlenmiş fiilin bütün özelliklerinden yola çıkılarak, özelikle suçun işleniş şekli ve suç aletini, vücuttaki hasarların sayısını, yerini ve özelliğini (örneğin hayati organların zarar görmesi), failin ve mă̆durun suçtan önceki ve sonraki davranışlarını ve onlar arasındaki ilişkiyi göz önüne almak gerekir". (Rusya Federasyonu Yüksek Mahkemesi’nin Kasten Öldürme Suçlarına İlişkin Mahkeme Uygulamaları Hakkındaki 27.01.1999 Tarih ve 1 No.lu Genel Kurul Kararı, http://www.supcourt.ru/ documents/ own/7794/, E. T.: 03.05.2020); Rusya Federasyonu Yüksek Mahkemesi’nin 02.08.2005 Tarih ve 66-o05-62 No.lu Karar1: “N’nin mağdurun hayati organlarına doğru iki el ateş etmesi öldürme kastının bulunduğunu gösterir”. (http://pravosudie.biz/ base1/data_sy/sudqsgbxv.htm, E. T.: 22.03.2011); Rusya Sovyet Federatif Sosyalist Cumhuriyeti (RSFSC) Yüksek Mahkemesi’nin kararına konu olan bir olayda; mağdur Ç’nin boğazına bıçakla vuran $\mathrm{M}$, mağdurun direnmesi üzerine ikinci darbede başarısız olmuş ve M, Ç’nin yardıma gelen etraftaki insanlar tarafından yakalanmıştır. Yüksek Mahkeme M'nin olası değil, doğrudan öldürme kastıyla hareket ettiğine ve dolayısıyla insan öldürmeye teşebbüsten cezalandırılması gerektiğine karar vermiştir. (1991 Yılı 1 No.lu Yüksek Mahkeme Bülteni, (Bkz. Rarog, Aleksey (Ed.): Ugolovnoye Pravo Rosii (Rusya Ceza Hukuku), Obşaya Çast (Genel Kısım), Moskva 2008, s. 135)). (Rus kaynaklarından alınmış mahkeme kararlarının bir kısmında tarih, karar numarası veya mahkeme adı belirtilmemiştir).

Dönmezer/Erman, s. 407.

Rusya Federasyonu Anayasası'nın 126. maddesine göre; Rusya Federasyonu Yüksek Mahkemesi, mahkeme uygulamalarına ilişkin açıklama yapma yetkisine sahiptir. Rusya Federasyonu Mahkemelerinin Kuruluşu Hakkındaki Kanunun 56. maddesine göre, bu yetki Rusya Federasyonu Yüksek Mahkemesi'nin Genel Kurulu tarafından kullanılır.

Karar için bkz. http://www.supcourt.ru/documents/own/7794/, E. T.: 03.05.2020; Kasten Öldürme Suçlarına İlişkin Mahkeme Uygulamaları Hakkındaki RSFSC Yüksek Mahkemesi'nin 22.12.1992 tarih ve 15 No.lu Genel Kurul kararı da aynı yöndedir. 
kastla işlenen suçlara teşebbüsün mümkün olmadığı kabul edilmektedir ${ }^{46}$. Çünkü uygulamada Rusya Federasyonu Rusya Federasyonu Yüksek Mah-

(Karar için bkz. http://www.supcourt.ru/documents/own/7723/, E. T.: 03.05.2020). Yine Kasten Öldürme Suçlarına İlişkin Mahkeme Uygulamaları Hakkındaki Sovyet Sosyalist Cumhuriyetler Birliği (SSCB) Yüksek Mahkemesi'nin 27.06.1975 tarih ve 4 No.lu Genel Kurul kararı da aynı yöndedir. (Karar için bkz. Kriger, German/Kuznesova, Ninel/Tkaçevkiy, Yuriy (Ed.): Sovetskoye Ugolovnoye Pravo (Sovyet Ceza Hukuku), Obşaya Çast (Genel Kısım), Moskva 1988, s. 168).

46 Bir olayda; kocası T'nin S ile ilişkisi olduğunu öğrenen $\mathrm{K}$, onların bulunduğu eve gelerek pencere camını, televizyon antenini kırmış ve elindeki benzinli şişeyi yakarak odaya atmıştır. Çıkan yangın sonucunda $\mathrm{S}$ ve $\mathrm{T}$ orta ağır derecede yaralanmışlardır. İlk derece mahkemesi K hakkında yangın suretiyle mala zarar verme suçundan ve iki kişiyi öldürmeye teşebbüsten cezaya hükmetmiştir. Ancak RSFSC Yüksek Mahkemesi K'nın olası öldürme kastıyla hareket ettiğine ve olası kastla işlenen suçlara teşebbüsün mümkün olmadığına karar vermiştir. Bu nedenle $\mathrm{K}$ hakkında verilen hüküm, yangın suretiyle mala zarar verme ve iki kişiyi kasten orta ağır derecede yaralama olarak değiştirilmiştir. (1983 Yılı 6 No.lu Yüksek Mahkeme Bülteni (Bkz. Kriger/Kuznesova/Tkaçevkiy (Ed.), s. 168)); Rusya Federasyonu Yüksek Mahkemesi Kararı: "Mahkeme Zub'un Siroskiy'i yaralanmaslyla ilgili somut olayı doğru tespit etmekle birlikte, onun davrantşını hatalı olarak insan öldürmeye teşebbüs olarak değerlendirmiştir. Kararda belirtildiği gibi, sanık mağdurun göğsüne ve kafasina ayaklartyla çok kez vurmuş, kendi hareketleriyle onun ölebileceğini öngörmüss ve bilinçli olarak bu neticenin gerçekleşmesine izin vermiştir. Mahkeme Zub'un olası kastla Siroskiy'i öldürmeye teşebbüs ettiği sonu-cuna varmıştır. Hâlbuki ceza kanununa göre, suça teşebbüs sadece doğrudan kastla mümkün olabilir. Bu nedenle Zub’un hareketleri kasten ăğr yaralama suçu olarak değerlendirilmelidir. (2004 Yılı 9 No.lu Yüksek Mahkeme Bülteni, http://www.supcourt.ru/files/10158/, E. T.: 03.05.2020); Rusya Federasyonu Yüksek Mahkemesi Kararı: "Çasıgov ile mağdurlar Podkorttov, Çetvertakov ve Karçegamin arasında yaşanan tartışma kavgaya dönmüs ve Çasıgov elindeki bıçakla mağdurlardan Podkoritov ve Çetvertakov'a bir kez, Karçegamin'e ise iki kez vurarak yaralamıştır. Bunun sonucunda Çetvertakov hafif, Karçemagin ve Podkorıtov ise ağır bir şekilde yaralanmışıtır. Olay sırasında yaralanan mağdurların hepsi aldıkları bıçak darbesine rağmen ayakta kalmışlardır. Ĕger Çasıgov mağdurları öldürmek isteseydi, olay esnasinda bu amacını gerçekleştirmesine herhangi bir engel bulunmamakta idi. Oysa O, başkaca bir girişimde bulunmadığı gibi, tam tersine olay yerinden kaçmıştır. Çasıgov ilk soruşturmada ve mahkemede de kimseyi öldürmek gibi bir niyetinin bulunmadığını ifade etmişstir. Çasıgov'un doğrudan değil, olası öldürme kasttyla hareket ettiği tespit edildiğine göre, onun gerçekleşebilecek neticelerden değil, gerçekleşen neticelerden, yani Karçegamin ve Podkarttov'u kasten ağır yaralamadan ve Çetvertakov'u kasten hafif yaralamadan sorumlu tutulması gerekir". (2004 Y1lı 3 No.lu Yüksek Mahkeme Bülteni, http://www.supcourt.ru/files/10053/, E. T.: 03.05.2020); Sverdlovsk Bölge Mahkemesi'nin 25.02.2009 Tarih ve 22-1752/2009 No.lu Karar1: "10.05.2008 tarihinde nehir kenarında alkollü içki içen sanık $B$ ile A arasında tartışma çıkmış ve $B$, karavanından aldığı av tüfeğiyle A'y korkutmak amacıyla havaya doğru ateş etmiştir. B, silahını tekrar doldurduğ u sırada $M, B$ 'nın elinden silahı almak istemiş ve bu mücadele sirasinda silahın patlaması sonucu M yaralanmıştır. Bunu gören K, kaçmakta olan B'yi kova- 
kemesi Genel Kurul kararlarının mahkemeleri bağlayıcı olduğu kabul edilmektedir ${ }^{47}$.

Rusya Federasyonu doktrininde de olası kastla işlenen suçlara teşebbüsün mümkün olmadığı konusunda görüş birliği bulunmaktadır ${ }^{48}$.

Türk doktrininde ise olası kastla işlenen suçlara teşebbüsün mümkün olup olmadı̆̆ konusu tartışmalıdır. Bu konudaki birinci görüş, olası kastın da kast kavramının kapsamında olduğunu ileri sürerek olası kastla işlenen suçlara teşebbüsün mümkün olduğunu savunmaktadır ${ }^{49}$. Bizim de katıldı-

larken, B, K'nın bulunduğu yöne doğru ateş etmiş ve mermi V'ye isabet ederek onu karnından yaralamıştır. $M$, aldlğı yara sonucu ölürken, $V$ ise yaralı olarak kurtulmuştur. Sisertskiy Illçe Mahkemesi B hakkinda ruhsatsı silah bulundurma (m.222/1), insan öldürmeye teşebbüs $(m .105, \mathrm{~m} .30 / 3)$ ve taksirle öldürme (m.105/1) suçlarından hüküm kurmuştur. Ancak B, savunmasında kendi hayatından endişe ettiğini, yani M'nin arkadaşlarının kendisini kovalamasını engellemek için hedef gözetmeksizin ateş ettiğini ifade etmiştir. Olayda sanı̆̆ın insan öldürmeye teşebbüsten sorumlu olabilmesi için doğrudan kastla hareket ettiğinin tespit edilmiş olmast gerekir. Fakat B'nin V'yi doğrudan kastla öldürmek istediği ispat edilememiştir. Olayda B'nin çok uzak mesafeden ateş ettiği de dikkate alındığında, belirsiz kastla hareket ettiğini kabul etmek gerekir. Yani sanık insanların bulunduğu yöne doğru ateş ederken herhangi bir neticenin gerçekleşmesini kabullenmiştir. Dolaylsiyla B'nin V'ye karşs işlediği fiilin hayati tehlikeye neden olan kasten ăğr yaralama olarak değerlendirilmesi gerekir. Bu nedenle $B$ hakkında RFCK'nın 105/1. ve 30/3. maddesinden (öldürmeye teşebbüs) verilen hükmün, değiștirilmesine (kasten ăğr yaralama (m.111/1)) ..." (Sverdklovsk Bölge Mahkemesi'nin Ceza Davaları Üzerine 2009 Yılı Bülteni, http://www.ekboblsud.ru/sudpr_det.php? srazd $=6 \& \mathrm{id}=50 \&$ page $=2$, E. T.: 03.05.2020); RSFSC Yüksek Mahkemesi'nin 1987 Tarihli Kararı: "Sanık ve mağdur arasındaki arkadaşlık ilişsisi olup, aralarındaki tartışma tesadüf sonucu ve mağdurun tahriki ile meydana gelmiştir. Mağdur, H'nin burnuna yumrukla ve kasığına tekmeyle vurmuştur. Bunun üzerine $H$, bıçağını çekerek mağduru bir kez göğsünden ve bir kez de sirtından biçaklamıştır. Daha sonra aralarındaki kavga sona ermiş ve $H$, mağduru öldürmek için herhangi bir girişimde bulunmamıştır. Mahkemenin, olayda saniğın öldürme kastıyla hareket ettiği yönündeki kanaati doğru değildir. Somut olayın özellikleri dikkate alındığında sanığın mağduru öldürmek istediği söylenemez. Tam tersine, deliller, sanık H'nin haksız fiilinin neden olduğu güçlü heyecanın etkisi altında belirsiz kastla mağduru bıçakladı̆̆ını göstermektedir. Bu nedenle, H'nin, somut olarak gerçekleşen neticelerden, yani kasten ağır yaralama suçundan sorumlu tutulmast gerekir”. (Bkz. Rarog (Ed.), s. 138).

Smirnov, Andrey: "O Yuridiçeskoy Sile Postanavleniy Plenuma Verhovnogo Suda Rossiyskoy Federasii (Rusya Federasyonu Yüksek Mahkemesi Genel Kurul Kararlarının Hukuki Gücü Hakkında)", Oteçestvennaya Yurisprudensiya, 2016, No:12 (14), https://legalscience.ru/images/PDF/2016/14/o-yuridicheskoj-sile-postanovlenij.pdf, E. T.: 02.05.2020.

Kuznesova/Tyajkova (Ed.), s. 371. 
ğımız ikinci görüş ise, olası kastla işlenen suçlara teşebbüsün mümkün olmadığını savunmaktadır ${ }^{50}$.

Taksirli suçlara teşebbüs mümkün değildir. Örneğin trafik kurallarını ihlal ederek tehlikeli araç kullanan kişi, trafik kazasına neden olmuş, ancak kimseye zarar vermemişse suça teşebbüsten değil, Rusya Federasyonu Kabahatler Kanunu'nda düzenlenen trafik kurallarını ihlal etme kabahatinden sorumlu olur ${ }^{51}$.

\section{B. Objektif Unsur (İcra Hareketlerine Başlama)}

\section{Genel Olarak}

Suça teşebbüs için failin işlemeyi kastettiği suçun doğrudan doğruya icrasına başlamış olması, fakat bu suçun failin elinde olmayan nedenlerle tamamlanmamış olması gerekir.

Sirf hareket suçlarına teşebbüs, kanunda belirtilen hareketin sadece bir kısmının yerine getirilmesi durumunda meydana gelir. Neticeli suçlara teşebbüs ise failin hareketin bir kısmını veya tamamını yapmasına rağmen, tipik neticenin gerçekleşmemesi durumunda meydana gelir. Ancak bu durum suça teşebbüste hiçbir neticenin bulunmadığı anlamına gelmez. Örneğin fail mağduru öldürmek için ateş etmiş, ancak mermi mağduru yaralamış ise, fail kasten yaralama suçundan değil, insan öldürme suçuna teşebbüsten sorumlu olur $^{52}$. Suça teşebbüste önemli olan failin kastettiği suçtaki tipik neticenin meydana gelmemiş olmasıdır.

İcra hareketlerine başlanmamış olması durumunda suça teşebbüsten değil, hazırlık hareketlerinden söz edilir.

\section{2. İcra Başlangıcının Tespitine İlişkin Teoriler}

\section{a. Sübjektif Teoriler}

Sübjektif teoriler icra başlangıcının tespitinde ölçü olarak failin iradesini esas almaktadır ${ }^{53}$. Bu teorilere göre; tipik sonucun meydana gelmemesi nedeniyle, teşebbüse ruh ve anlam kazandıran, failin suç işlemeye yönelik

50 Hafızoğulları/Özen, s. 309; Demirbaş, Timur: Ceza Hukuku, Genel Hükümler, 10. Bask1, Ankara 2014, s. 446; Toroslu, s. 262-263; İçel/Evik, 239; Özgenç, İzzet: Türk Ceza Hukuku, Genel Hükümler, 11. Bask1, Ankara 2015, s. 470.

51 Kuznesova/Tyajkova (Ed.), s. 364.

52 Naumov, Anatoliy: (Tercüme: Qurbanov H.), Rusya Cinayet Hüququ, Ümumi Hisse, Bak1 1998, s. 304.

53 Öztürk/Erdem, s. 320. 
kastıdır. Bu görüşlere göre teşebbüste cezalandırılan hareket, suçlu iradenin şüpheye yer vermeyecek şekilde ortaya konulmasıdır ${ }^{54}$.

Sübjektif teoriyi benimseyen bazı yazarlar, teşebbüs konusunda, sübjektif ölçütleri en aşırı biçimde uygulama isteği ile hareket ederler. $\mathrm{Bu}$ yazarlara göre, failce yapılan herhangi bir hareketin, bir suçu gerçekleştirmek üzere dış dünyaya yansıdığının tespiti halinde, icra hareketine başlanmış olur. Failin tehlikelilik halini esas alan bu görüşler, dış bir hareketle failin tehlike halini ortaya koymasını teşebbüsün cezalandırılması bakımından yeterli görmektedirler ${ }^{55}$. Dolayısıyla bu yazarlar, failin sonuca çok uzak bir hareketinin bile, suç işleme amacıyla yapılmışsa icra başlangıcı sayılacağını kabul ederler. Öyle ki, bu görüşü savunan bazı yazarlara göre, düşmanını öldürmek amacıyla onun bulunduğu şehre tren bileti alan kişi bile cezalandırılmalıdır ${ }^{56}$.

Sübjektif teoriyi benimseyen diğer bazı yazarlar ise, faildeki suç işleme kastının açık ve kesin biçimde tipik sonucu gerçekleştirmeye yönelik oldugunun tespiti halinde, icranın başlamış olduğunu ileri sürerler ${ }^{57}$. Buna göre, failin suç işleme kastını daha açık bir şekilde ortaya koyan, failin suç işleme iradesini kesin ve geri dönülmez biçimde belirten hareketler varsa, başka bir ifadeyle, fail, suç işleme kastından şüphe duyulmayacak biçimde sonuca yaklaştığını ifade eden hareketleri yapmışsa icra hareketlerine başlanmıştır ${ }^{58}$.

Sübjektif teoriler, ceza sorumluluğunu aşırı genişletmesi nedeniyle eleştirilmiştir. Çünkü bu teorilere göre; yapılan hareketlerin, failin belirli bir suçu işleme iradesini ortaya koyması icranın başladığının kabulü için yeterlidir. Sübjektif kriterler esas alındığında, aslında hazırlık hareketi niteliğinde olan birçok hareket, icra hareketi sayılmaktadır. Bu durum, kişi hak ve özgürlükleri açısından sakıncalı durumlar ortaya çıkarabiliir ${ }^{59}$.

\section{b. Objektif Teoriler}

Objektif teoriler, hazırlık-icra hareketi ayrımının, failin suç işleme kastına yönelik olarak gerçekleştirdiği maddi nitelikli hareketlere göre yapılmasını savunmaktadırlar ${ }^{60}$.

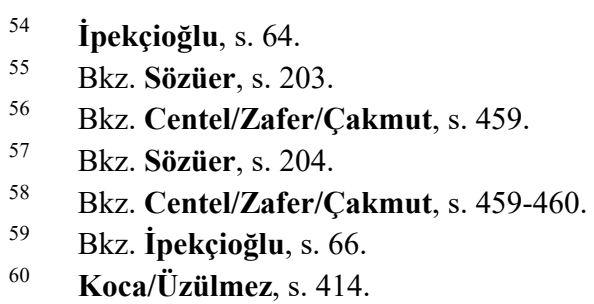




\section{aa. Şüpheye Yer Vermeme Teorisi (Tek Anlamlı Hareket Teorisi)}

Bu görüşe göre; hareket failin bir suça yöneldiğini şüpheye yer vermeyecek şekilde ortaya koyabiliyorsa icra hareketi, buna karşılık failin gerçekleştirdiği hareketin, hangi suça yönelik olduğu kesin olarak belirlenemiyorsa, hazırlık hareketi olarak değerlendirilir ${ }^{61}$. Eğer bir hareketin yöneldiği amaç konusunda farklı yorumlar yapılabiliyorsa, o hareket hazırlık hareketidir $^{62}$.

$\mathrm{Bu}$ görüş, şüpheye yer vermeme konusunda ayırım yapmanın mümkün olmadığ1 gerekçesiyle eleştirilmiştir. Çünkü bir suça yöneldiğinde şüphe olmayan bir hareketin hazırlık hareketi, şüpheli bir hareketin icra hareketi olması mümkündür. Bu teori kabul edildiğinde çok kolay bir şekilde hazırlık hareketleri cezalandırılacaktır. Örneğin bir kişinin başkasından tehditle para almak yazıp cebine koyduğu, fakat henüz postalamadığı bir mektubun suça yönelmiş olduğu konusunda şüphe yoktur. Fakat mektup henüz cepte bulunduğundan yapılan hareket hazırlık hareketidir. Oysa şüpheye yer vermeme kriteri kabul edildiğinde, bu hareketin cezalandırılması gerekir. Yine pencereye merdiven dayayan kişinin hareketi hiç şüphesiz konut dokunulmazlığını ihlal konusunda icra hareketidir. Fakat insan öldürme veya hırsızlık konusunda şüpheli bir harekettir ${ }^{63}$.

\section{bb. Mă̆durun Faaliyet Alanına Taşıma Teorisi}

$\mathrm{Bu}$ görüşe göre, failin faaliyet alanında kalan hareketler hazırlık hareketleri, buna karşılık mağdurun faaliyet alanına giren hareketler ise icra hareketleridir ${ }^{64}$. Bu görüş de failin faaliyet alanı kavramının belirsiz olduğu iddiasıyla eleştirilmiştir ${ }^{65}$.

\section{cc. Biçimsel Objektif Teori}

$\mathrm{Bu}$ teoriye göre, hareket, suç tipinin unsur veya nitelikli hallerinden birisini oluşturuyor ise icra hareketi; buna karşıllk suç tipinde öngörülmeyen

61 Bkz. İpekçioğlu, s. 55; Türk doktrininde Hafizoğullar/Özen bu görüşü benimsemektedir. (Hafızoğulları/Özen, s. 312-313). Bkz. Soyaslan, s. 66.

Soyaslan, s. 67; Carrara tarafindan ileri sürülen şüpheye yer vermeme teorisi, daha sonraları bu ölçütün hareketin mahiyetine ilişkin bir sorunu, failin kastını kanıtlamaya ilişkin bir sorunla karıştırma sonucunu doğurduğu gerekçesiyle yazarın kendisi tarafindan da eleştirilmiştir (Bkz. Tozman, s. 84). 
bir hareket söz konusu ise hazırlık hareketinden söz edilir ${ }^{66}$. Örneğin, bir insana ateş etmek, kasten öldürme suç tipindeki öldürmek sözcüğüne girdiğinden icra hareketi sayılır. Fakat, ateş etme hareketinden önceki silahın omuza dayatılması, emniyet mandalının düşürülmesi ve nişan alma gibi hareketler hazırlık hareketidir ${ }^{67}$.

$\mathrm{Bu}$ teori, aslında icra hareketi olarak kabul edilmesi gereken durumların cezasız kalmasını sonuçlaması nedeniyle eleştirilmiştir ${ }^{68}$. Örneğin hırsızlık yapmak için bahçe duvarını aşan veya evin kapısını kıran kimse, hırsızlık suçunun tipik hareketi olan başkasına ait taşınır malı bulunduğu yerden almış olmamaktadır ${ }^{69}$.

\section{dd. Maddi Objektif Teori}

Maddi objektif teori, hareketin suç tipiyle şekli değil, maddi bağlantısını esas alarak icra başlangıcını belirlemektedir ${ }^{70}$.

Maddi objektif teorilerden biri olan Frank teorisine göre, suçun tanımında öngörülen fiille olan zorunlu bağlılığı dolayısıyla tipik hareketin ayrılmaz bir parçası olarak görülen hareketler icra hareketi, bu tür zorunlu bir bağllı̆ğı belirlenemeyen hareketler ise hazırlık hareketidir ${ }^{71}$. Örneğin tüfeğin omuza konulması, nişan alma, emniyet mandalını indirme faaliyetleri doğal anlamda ateş ederek öldürme hareketiyle bir bütünlük içinde olduklarından, bu davranışlar icra başlangıcı niteliğindedir ${ }^{72}$.

Frank teorisi, icra hareketlerine zorunlu olarak bağlı ve bu hareketlerle doğal bir bütünlük oluşturan hareketleri belirlemede belli ve sağlam bir kriter sunmaması nedeniyle eleştirilmiştir ${ }^{73}$.

Yine maddi objektif teori kapsamında olan ve bizim de taraftarı olduğumuz tehlike teorisine göre, normla korunan hukuki yararı ihlal eden hareketleri icra, bundan önceki hareketleri ise hazırlık hareketi olarak değerlendirilmelidir. Buna göre, suçun icrasına başlanıldığının kabulü için, hukuken korunan menfaatin "doğrudan veya somut" olarak bir tehlikeye maruz bıra-

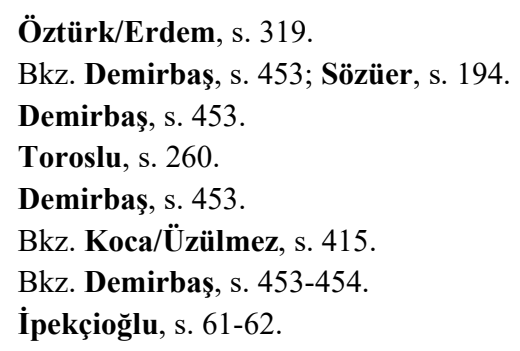


kılması gerekir. Tehlikenin varlığı ise, ortalama bir insanın sahip bulunduğu genel hayat tecrübelerine göre, ex ante bir şekilde değerlendirilecektir ${ }^{74}$.

Tehlike teori ise suç konusunun doğrudan veya somut biçimde tehlikeye düşürülmesinin kesin olarak belirlenemeyeceği, olayların farklılıği nedeniyle her olay için geçerli ve belirli bir tehlike derecesinden bahsedilemeyeceği ve dolayısıyla bu kriterin keyfi uygulamalara çok müsait olduğu ileri sürülerek eleştirilmiştir ${ }^{75}$.

\section{c. Karma Teoriler}

Karma teoriler icra başlangıcı konusunda sübjektif bir temele dayanmakla birlikte, bunu objektif ölçülerle tamamlamaktadırlar ${ }^{76}$.

Welzel'e göre, "teşebbüs failin kendi suç planına göre, kanuni suç tipini doğrudan doğruya gerçekleştirmek üzere giriştiği faaliyetle başlar”; dolayısıyla failin planı, yapılan hareketin icra olup olmadığını belirler ${ }^{77}$. Schröder ise "suç iradesini ortaya koyan hareket, ĕger failin planına göre suç konusunu doğrudan tehlikeye koyuyorsa icra hareketlerine başlandığııı" ileri sürmektedir. Örneğin, failin bir evi gözetlerken yakalanması durumunda; eğer fail gözetleme esnasında en uygun firsat ve yeri bulur bulmaz eve girmeyi düşünüyorsa, icra hareketleri başlamıştır. Buna karşılık eğer fail gözetleme ve bilgi toplamayı bitirip daha sonra hırsızlığa elverişli araçlarla tekrar dönüp eve girmeyi planlamışsa, bu durum hazırlık hareketi olarak görülecektir ${ }^{78}$.

\section{d. Türk Ceza Hukukunda Benimsenen Teori}

TCK'nın 35. maddesinde, "doğrudan doğruya icraya başlayıp" ifadesinin kullanılmış olması ve gerekçesinde "Böylece işlenmek istenen suç tipiyle belirli bir yakınlık ve bağlantı içindeki hareketlerin yapılması durumunda suçun icrasına başlanılmış sayılacaktır" denilmiş olması nedeniyle icra başlangıcı konusunda maddi objektif teori benimsenmiş olmaktadır ${ }^{79}$.

\section{e. Rusya Federasyonu Ceza Hukukunda Benimsenen Teori}

Rusya Federasyonu Ceza Kanunu'nda “doğrudan doğruya suçun işlenmesine yönelik hareketler" suça teşebbüs sayıldığ 1 için, icra başlangıc1

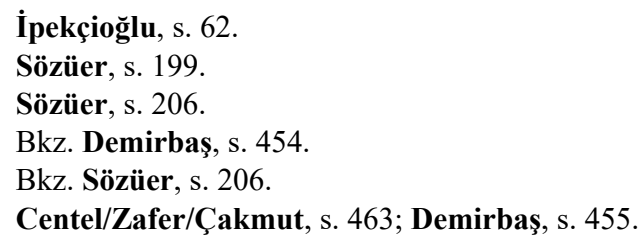


konusunda maddi objektif teorinin benimsendiği söylenebilir ${ }^{80}$. Doktrinde de genellikle maddi objektif teorinin savunulduğu görülmektedir. Ancak bununla birlikte biçimsel objektif teoriyi savunan yazarlar da bulunmaktadir ${ }^{81}$. Rusya Federasyonu Yüksek Mahkemesi de bazı kararlarında biçimsel objektif teoriyi uygulamıştır ${ }^{82}$.

Rusya Federasyonu Yüksek Mahkemesi'nin 24.03.2010 Tarihli Kararı: “A ve V, S'yi öldürmek amacıyla mağdurun yazlık evinin bağımsız mutfă̆ına girmiş, A, orada bulduğu demir çubuğu suçta kullanmak için hazırlık yaptığı sırada, onun hareketleri polisler tarafindan durdurulmuştur. Yani suçun faili olan A'nın hareketleri S'yi öldürmeye teşebbüs ettiği aşamada değil, bu suça hazırlık yaptı̆̆ aşamada durdurulmuştur. A, polisler tarafindan yakalandığı için, doğrudan doğruya mağduru öldürmeye yönelik hareketleri gerçekleștirememiştir. Bu nedenle sanıkların hareketlerini insan öldürmeye hazırlık olarak değerlendirmek gerekir". (2010 Y1l1 6 No.lu Yüksek Mahkeme Bülteni, http://www.supcourt.ru/files/13321/, E. T.: 03.05.2020); Rusya Federasyonu Yüksek Mahkemesi Kararı: “Olayda, markette yapılan kontrol sirasında, satıcı P'nin son kullanma tarihi geçmiş olan salamı satılması için vitrinde bulundurduğu tespit edilmiştir. Olay sırasında müststerilerden herhangi biri bu salamı satın almadığından veya satın almak için bir harekette bulunmadı̆̆ından P'nin hareketinin tüketicileri aldatma suçuna hazırlı niteliğinde olduğunu kabul etmek gerekir. RFCK'nın 30/2. maddesine göre, sadece ă̆ır ve nitelikli ă̆ır suçlara hazırlık ceza sorumluluğuna sebep olduğundan ve RFCK'nın 200. maddesinde düzenlenen tüketicileri aldatma suçu hafif suç olduğundan, P'nin fiili herhangi bir suç niteliği taşımamaktadır. Bu nedenle, ilk derece mahkemesinin P hakkında tüketicileri aldatma suçuna teşebbüsten kurduğu hüküm hatalıdır". (2002 Y11 10 No.lu Yüksek Mahkeme Bülteni), http://www.supcourt.ru/files/10588/, E. T.: 03.05.2020); Smolenskiy Bölge Mahkemesi'nin 2009 Tarihli Kararı: “A'nın davranışı uyuşturucu satma suçuna teşebbüs değil, bu suça hazırlık olarak değerlendirilmelidir. $O$, uyuşturucu maddeyi teslim ettiği sırada değil, onu satmaya hazırlık yaptı̆̆ (ıslaevine sokmaya çalıştığı) sırada yakalanmıştır". (http://oblsud.sml.sudrf.ru/modules. php?name=docum_sud\&id=181, E. T.: 03.05.2020).

$\operatorname{Rarog}($ Ed.), s. 185.

Rusya Federasyonu Yüksek Mahkemesi'nin 16.06.2010 ve 89-o10-13 No.lu Karar1: "22-23 Aralık 2008 tarihinde Tyumen şehrindeki bir fabrika bölgesinde çıkan kavga sırasında $D, Y$ ve $Z$, R'nin elindeki bıçağı onun elinden almış, onu ve onun yardımına gelen B'yi dövmüsslerdir. Daha sonra mağdurların polise başvuracaklarından endişe eden $Z$, onlar öldürmeyi teklif etmiş ve bunun üzerine $D, Y$ ve $Z, R$ ve B'yi zorla nehir kenarına götürmüs ve orada R'yi bıçaklayıp ağır bir şekilde yaraladıktan sonra, onu buzda açılan delikte boğmuşlardır. Bu sırada mağdur B, kaçıp saklanmayı başarmış ve dolayısıyla sanıklar ona karşı işlemek istedikleri suçu tamamlayamamışlardır. Olayda $B$, nehir kenarına ilerde öldürülmek amacıyla getirilmiştir. Yani onun öldürülmesi için ortam yaratılmış, fakat sanıklardan hiçbirisi doğrudan doğruya öldürmeye yönelik hareketleri gerçekleştirmemiştir. Bu koşullarda sanıkların B'ye karşı olan hareketlerini insan öldürmeye teşebbüs olarak değil, insan öldürmeye hazırlık olarak kabul etmek gerekir". (2011 Y1l1 2 No.lu Yüksek Mahkeme Bülteni, http://www.supcourt.ru/files/ 13520/, E. T.: 03.05.2020); Bir olayda sarhoş durumda olan O, satıcı olarak çalışan E'nin evinin bulunduğu yere gelmiş, evin kapısına vurarak ondan kendisine bir şişe 
Sereteli'ye göre; doğrudan doğruya suçun işlenmesine yönelik hareketler, sonucun gerçekleşmesine neden olmasa bile, yasayla korunan konunun "doğrudan ve somut" tehlikeye maruz kalmasina neden olan hareketlerdir. $\mathrm{Bu}$ tür hareketler engel nedenler bulunmadiğında sonucun gerçekleşmesine neden olur ${ }^{83}$. Örneğin, mağduru öldürmek amaciyla failin mağdurun evinin kapısını kırması, mağdurun vücut bütünlüğüne etki etmediğinden ve insan hayatı için doğrudan tehlike yaratmadığından hazırlık hareketi olarak değerlendirilmelidir. Aynı hareketin hırsızlık amacıyla yapılması ise hırsızlık suçuna teşebbüs sayılmalıdır ${ }^{84}$.

Naumov'a göre; suça hazırlıktan farklı olarak, suça teşebbüste fail suçun hukuki konusuna doğrudan etki etmektedir. Örneğin fail mağdura ateş eder, ancak mermi boşa gider. Burada fail ateş ettiği anda mağdurun hayatı "doğrudan ve somut" tehlikeye maruz kalmaktadır. Yazara göre; eğer yapılan hareket suçun maddi unsurunun bir kısmını oluşturuyor ise icra hareketi, oluşturmuyor ise hazırlık hareketi sayılır. Durum böyle olunca, aynı hareket bir suçta icra hareketi iken, bir başka suçta hazırlık hareketi sayılabilir. Örneğin hırsızlık amacıyla konuta girilmesi icra hareketidir. İnsan öldürmek

votka satmasını talep etmiştir. O'nun bu talebi geri çevrilmiş, ancak $\mathrm{O}$, kapıya vurmaya devam etmiştir. Bunun üzerine E'nin kocası dışarı çıkarak O'ya yaptığı çirkinliğe son vermesini söylemiştir. Tüm bunlara alınan $\mathrm{O}$, E'yi öldüreceğini söylemiş, evine giderek dolu tüfeğini almış, tekrar E'nin evinin bulunduğu yere gelmiş ve E'yi öldüreceği konusunda bağırarak tehditler savurmuştur. O esnada 25-30 metre uzaklıkta duran E'nin kocasını fark eden $\mathrm{O}$, "seni öldüreceğim" diye bağırmış ve tüfeğini hazır konuma getirerek E'nin kocasına doğru koşmuştur. Ancak $\mathrm{O}$, olay yerine yetişen kolluk görevlisi Ç tarafindan yakalanarak etkisiz hale getirilmiştir. Bu olayda O'nun davranışları suçun işlenmesi için kasten farklı ortam yaratma, yani insan öldürme suçuna hazırlık olarak değerlendirilmiştir. (1961-1963 Yılı RSFSC Yüksek Mahkemesi Genel Kurul, Başkanlik ve Ceza Daireleri Kararlar Dergisi, Moskva 1964, s. 81-82, (Bkz. İgnatov, Aleksey/ Krasikov, Yuriy (Ed.): Ugolovnoye Pravo Rosii (Rusya Ceza Hukuku), Obşaya Çast (Genel Kısım), Tom 1 (Cilt 1), Moskva 2000, http://lib.maupfib.kg/wp-content/uploads/ Ugolovnoe-pravo-Rossii_v-2t_T-1-Obshhaya-chast_Pod-red-Ignatova-Krasikova_2000639s.pdf, E. T.: 02.05.2020, s. 127).

83 Sereteli, Tinatin: "Nakazuyemost Prigotovleniya k Prestupleniyu po Sovetskomu Ugolovnomu Pravu (Sovyet Ceza Hukukuna Göre Suça Hazırlığın Cezalandırılabilirliği)", Sosialistiçeskaya Zakonnost, No:12, 1954, s. 11.

84 Sereteli, s. 14; Aynı görüşte: Traynin, Aron: "Ugolovnaya Otvetstvennost za Prigotovitelnıye k Prestupleniyu Deystviya (Suça Hazırlık Hareketlerinden Dolayı Ceza Sorumluluğu)", Sosialistiçeskaya Zakonnost, No:12, 1953, s. 31; Aksi görüşte Veliyev: "Mağduru öldürmek amacıyla failin mağdurun evinin kapısını kırması, mağdurun hayatı için doğrudan tehlike yaratmaktadır ve insan öldürmeye teşebbüs olarak değerlendirilmelidir”. (Veliyev, Samir: Cinayete Hazırlığa ve Cinayet Etmeye Cehde Göre Mesuliyet Meseleleri, Bak1 2001, s. 130). 
amaciyla konuta girilmesi ise hazırlık hareketidir. Çünkü ikinci örnekte yapılan hareket insan öldürme suçunun maddi unsuru kapsamında değildii ${ }^{85}$.

Grişaev/Zdravomıslov'a göre; suça teşebbüste suçun hukuki konusu doğrudan tehlikeye maruz kalmışken, suça hazırlıkta böyle bir tehlike bulunmamaktadır. Örneğin fail öldürmek kastıyla mağdura silahla ateş ettiğinde mağdurun hayatı; mağdurun evine hırsızlık için girdiğinde ise mağdurun mülkiyet hakkı doğrudan tehlikeye maruz kalmaktadır. Dolayısıyla suçun hukuki konusunun doğrudan tehlikeye maruz kalma anı, icra hareketlerine başlama anı olarak kabul edilmelidir ${ }^{86}$.

Piontkovskiy'e göre; hazırlık hareketleri, ilerde işlenecek suç için ortam yaratmak olup, hukuki konu için doğrudan bir tehlike oluşturmamaktadır. Buna karşl11k, icra hareketleri hukuki konu için somut ve doğrudan bir tehlike oluşturmaktadır. Örneğin fail mağdura ateş etmiş, ancak mermi boşa gitmişse, fail ateş ettiği sırada mağdurun hayatı somut tehlikeye maruz kalmıştır ${ }^{87}$.

Tagansev'e göre; konutta hırsızlık durumunda, eve girilmesi ve eşyaların alınması icra hareketi sayılmalıdır. Buna karşılık merdiven getirilmesi, merdivenin pencereye dayatılması gibi konuta girmeyi mümkün hale getiren hareketler ise hazırlık hareketi sayılmalıdır. Yine yazara göre; mağduru gizlice zehirlemek isteyen failin zehir elde etmesi, bu zehri içeceğe katması, bu içeceği mağdura doğru götürmesi hareketleri suça hazırlık sayılmalıdır. Buna karşılık failin bu içeceği mağdura sunma hareketi icra başlangıcı sayılmalıdır. Ancak eğer fail bu içeceği mağdurun içmesini beklemek üzere mağdurun önündeki masaya koyarsa, yine icra hareketlerine başlanmış sayılmaz. Bu durumda ise mağdur zehirli içeceği eline alarak ağzına doğru götürürse, ancak o zaman icra hareketlerine başlanmış olur ${ }^{88}$.

Tişkeviç'e göre; doğrudan doğruya suçun işlenmesine yönelik hareketler, tamamlanmış suçu meydana getirmeleri mümkün olan hareketlerdir. Yazara göre; failin mağdura nişan alması, hırsızlık amacıyla kilidi kırması gibi hareketler de icra hareketi sayılır. Çünkü engel nedenler bulunmadığ durumlarda bu tür hareketler suçun tamamlanmasına neden olabilir. Aynı şekilde elverişsiz teşebbüs hallerinde de failin hareketleri tamamlanmış suçu

\footnotetext{
85 Naumov, s. 302-303.

86 Grişaev, Pavel/Zdravomislov, Boris: Sovetskoye Ugolovnoye Pravo (Sovyet Ceza Hukuku), Çast Obşaya (Genel Kısım), Moskva 1982, s. 200-201.

87 Piontkovskiy, s. 409.

88 Tagansev, Nikolay: Ugolovnoye Pravo (Ceza Hukuku), Obşaya Çast (Genel Kısım), Çast 1 (1. Bölüm), Po İzdaniyu 1902 Goda (1902 Y1lı Baskısına Göre), 2003, http://www.allpravo.ru/library/doc101p0/instrum105, E. T.: 02.01.2010, s. 165.
} 
meydana getirebilecek hareketlerdir. Çünkü elverişsiz teşebbüs hallerinde, fail yanılmasaydı, hareketleri suçun tamamlanmasına neden olabilirdi ${ }^{89}$.

Kuznesova'ya göre; hazırlık hareketleri başlı başına suç tipindeki sonucu meydana getirebilecek hareketler değildir. Buna karşılık icra hareketleri kendiliğinden doğrudan suç tipindeki sonucu meydana getiren hareketlerdir ${ }^{90}$.

Durmanov'a göre; failin elverişsiz araçlarla suçun icrasına başladığ1 durumlarda, kanuni tipteki hareketi gerçekleştirdiğinden söz edilemez. Yine elverişsiz teşebbüs hallerinde, hukuki konunun somut bir tehlikeye maruz kaldığı da söylenemez. Bu yüzden teşebbüsü hazırlık hareketlerinden ayıran nokta, teşebbüste failin iradi hareketlerinin doğrudan doğruya suçun işlenmesine yönelik olması, yani hukuki konunun doğrudan ihlal edilmesidir ${ }^{91}$. Yani yazara göre, biçimsel ve maddi objektif teorinin kabulü halinde işlenemez suç hallerinin neden cezalandırıldığı açıklanamaz. Ancak yazarın hazırlık-icra hareketi ayırımı için önerdiği "hukuki konunun doğrudan ihlal edilmesi" kriterinin, "hukuki konunun somut tehlikeye maruz kalmasi" kriteri ile aynı şey olduğu ileri sürülmüştür ${ }^{92}$. Kanaatimizce Durmanov'un işlenemez suç konusunda yapmış olduğu tespit doğru olmakla birlikte, hazırlık-icra hareketi ayırımı konusunda önerdiği kriter doğru değildir. Çünkü işlenemez suç durumlarında hukuki konunun doğrudan ihlal edildiğinden de söz edilemez.

\section{Eksik - Tam Teșebbüs Ayırımı}

Rusya Federasyonu Ceza Kanunu'nda eksik-tam teşebbüs ayırımı bulunmamakla birlikte ${ }^{93}$, uygulama bakımından önemli olması nedeniyle,

89 Tişkeviç, İvan: Prigotovleniye i Pokuşeniye po Sovetskomu Ugolovnomu Pravu (Sovyet Ceza Hukukuna Göre Hazırlık ve Teşebbüs), Moskva 1958, s. 87-88.

90 Kuznesova, Ninel: İzbrannıye Trudı (Seçilmiş Çalışmaları), Sankt-Peterburg 2003, s. 300 .

91 Durmanov, Nikolay: Stadii Soverşeniya Prestupleniya (Suçun İşlenme Evreleri), Moskva 1955, s. 106, 111-112.

92 Piontkovskiy, s. 410.

93 Eksik - tam teşebbüs ayırımı 1926 ve 1960 tarihli RSFSC ceza kanunlarında da bulunmamaktadır. 1922 tarihli Rusya Sovyet Federatif Sosyalist Cumhuriyeti Ceza Kanunu'nun (RSFSCCK) 13. maddesinde ise dolaylı olarak eksik ve tam teşebbüsün tanımı yapılmışı̧ı. Söz konusu düzenlemeye göre; "Fail amacını gerçekleştirmek için gerekli olan her şeyi yapamadiğında veya gerekli olduğunu düşündüğ̈̈ her şeyi yapmasına rağmen, elinde olmayan nedenlerle neticenin gerçekleşmemesi halinde, suç işlemeye yönelik hareketler suça teşebbüs sayılır". Ancak doktrinde haklı olarak bu tanımın yanlış olduğu ifade edilmiştir. Çünkü maddede eksik teşebbüs bakımından 
doktrinde eksik-tam teşebbüs ayırımı yapılmaktadır. Çünkü RFCK'nın 60/3. maddesinde cezanın belirlenmesi sırasında mahkemenin suçun sosyal tehlikelilik derecesini dikkate alması gerektiği hükme bağlanmıştır. Kuşkusuz failin tamamlanmış suça daha çok yaklaşması sebebiyle, tam teşebbüs, eksik teşebbüse oranla sosyal açıdan daha tehlikeli sayılır ve bunun cezanın belirlenmesi sırasında dikkate alınması gerekir. Ayrıca eksik-tam teşebbüs ayırımı gönüllü vazgeçme bakımından da önemlidir ${ }^{94}$. Çünkü Rusya Federasyonu ceza hukukunda gönüllü vazgeçme eksik teşebbüs hallerinde mümkündür. Tam teşebbüs hallerinde ise gönüllü vazgeçmeden değil, etkin pişmanlıktan söz edilebilir.

Ancak Rusya Federasyonu doktrininde eksik-tam teşebbüs ayırımının hangi kritere göre yapılması gerektiği tartışmalıdır.

Objektif kriteri esas alan birinci görüşe göre ${ }^{95}$, eksik-tam teşebbüs ayırımı, suçun tamamlanması için gerekli olan hareketlerin somut olarak gerçekleşip gerçekleşmediğine göre yapılmalıdır. Buna göre, fail suçun tamamlanması için gerekli olan tüm hareketleri gerçekleştirmişse, tam teşebbüsten söz edilir. Buna karşılık, fail suçun tamamlanması için gerekli olan hareketlerin sadece bir kısmını gerçekleştirmişse, eksik teşebbüsten söz edilir.

$\mathrm{Bu}$ görüş, suçun tamamlanması için gerekli olan hareketlerin tamamının gerçekleştirilmesi halinde, zaten genellikle suçun tamamlanmış olacağı ve böylece tam teşebbüs örneklerinin azalacağ 1 gerekçesiyle eleştirilmiştir ${ }^{96}$. Örneğin bu görüşün kabul edilmesi halinde, mağdura nişan almanın çok zor olduğu bir mesafeden ateş eden failin fiili, eksik teşebbüs olarak değerlendirilecektir. Çünkü bu örnekte, fail mağdura yaklaşmayarak, gereken tüm hareketleri gerçekleştirmemiştir. Rusya Federasyonu ceza hukukunda cezalandırılan elverişsiz teşebbüs hallerinin tümünün eksik teşebbüs sayılmasına neden olacağı, bu görüşe getirilen bir diğer eleştiridir ${ }^{97}$.

objektif kriter esas alınmışken, tam teşebbüs bakımından sübjektif kriter esas alınmıştır. (Durmanov, s. 147; Tişkeviç, s. 158).

Naumov, s. 307; Kriger, German/Kurinov, Boris/Tkaçevskiy, Yuriy (Ed.): Sovetskoye Ugolovnoye Pravo (Sovyet Ceza Hukuku), Obşaya Çast (Genel Kısım), Moskva 1981, s. 239-240.

Şargorodskiy, Mihail: Vina i Nakazaniye v Sovetskom Ugolovnom Prave (Sovyet Ceza Hukukunda Kusur ve Ceza), Moskva 1945, s. 26-27; Tişkeviç, s. 159; Zagorodnikov, Nikolay: Sovetskoye Ugolovnoye Pravo (Sovyet Ceza Hukuku), Obşaya i Osobennaya Çast (Genel ve Özel Kısım), Moskva 1975, s. 120.

Kriger/Kurinov/Tkaçevskiy (Ed.), s. 240; Piontkovskiy, s. 427.

Tagansev, s. 167. 
Sübjektif kriteri esas alan ikinci görüşe göre ${ }^{98}$, eksik-tam teşebbüs ayırımı failin iradesine göre yapılmalıdır. Buna göre, fail suçun tamamlanması için gerekli olduğunu düşündüğü tüm hareketleri gerçekleştirmişse, tam teşebbüsten söz edilir. Buna karşılık, fail suçun tamamlanması için gerekli olduğunu düşündüğü hareketlerin sadece bir kısmını gerçekleştirmişse, eksik teşebbüsten söz edilir.

$\mathrm{Bu}$ görüş ise aslında gerçekte icra hareketlerinin tamamlanmasına rağmen, failin bu hareketlerin yetersiz olduğunu düşündüğü durumlarda gereksiz yere fiilin eksik teşebbüs olarak değerlendirilmesi sonucunu doğuracağ1 gerekçesiyle eleştirilmiştir ${ }^{99}$.

Üçüncü görüşe göre ${ }^{100}$ ise, eksik-tam teşebbüs ayırımı hem objektif, hem de sübjektif kriter esas alınarak yapılmalıdır. Bu görüşe göre, fail suçun tamamlanması için gerekli olduğunu düşündüğü ve suçun tamamlanması için gerçekten de gerekli olan tüm hareketleri gerçekleştirmişse, tam teşebbüsten söz edilir. Buna karşılık, fail suçun tamamlanması için gerekli olduğunu düşündüğü ve suçun tamamlanması için gerçekten de gerekli olan hareketlerin sadece bir kısmını gerçekleştirmişse, eksik teşebbüsten söz edilir.

$\mathrm{Bu}$ görüş de failin düşüncesindeki icra hareketleri ile somut olarak suçun tamamlanması için gerekli olan icra hareketlerinin çakışacağ 1 varsayımından hareket ettiği gerekçesiyle eleştirilmiştir. Örneğin fail depodaki eşyaların tamamını yok etmek için yangın çıkarmış, ancak yakılan ateş kendiliğinden sönmüş olabilir. Bu örnekte, failin düşüncesine göre icra hareketleri tamamlanmış ise de somut olarak icra hareketleri tamamlanmamiştır ${ }^{101}$.

Naumov, s. 306-307; Rarog (Ed.), s. 187; Korolkov, A. (Ed.): Kommentariy k Ugolovnomu Kodeksu Rossiyskoy Federasii (Rusya Federasyonu Ceza Kanunu'nun Şerhi), Moskva 2004, s. 86-87; Zdravomıslov, Boris (Ed.): Ugolovnoye Pravo Rossiyskoy Federasii (Rusya Federasyonu Ceza Hukuku), Obșaya Çast (Genel Kısım), Moskva 1999, s. 228-229; Solopanov, Yulian (Ed.): Sovetskoye Ugolovnoye Pravo (Sovyet Ceza Hukuku), Obşaya i Osobennaya Çast (Genel ve Özel Kısım), Moskva 1981, s. 91-92; Magomedov, Asbeg: Ugolovnoye Pravo Rosii (Rusya Ceza Hukuku), Obşaya Çast (Genel Kısım), Moskva 1997, s. 58; Revin, Valeriy (Ed.): Ugolovnoye Pravo Rosii (Rusya Ceza Hukuku), Obşaya i Osobennaya Çast (Genel ve Özel Kısım), Moskva 2000, s. 213; Ter-Akopov, Arkadiy: Dobrovolnıy Otkaz ot Soverşeniya Prestupleniya (Suç İşlemekten Gönüllü Vazgeçme), Moskva 1982, s. 43-44; Durmanov, s. 146; Piontkovskiy, s. 425-426.

99 Tagansev, s. 167.

100 Kozaçenko, İvan/Neznamova, Zinaida (Ed.): Ugolovnoye Pravo (Ceza Hukuku), Obşaya Çast (Genel Kısım), Moskva 1997, s. 222; Vetrov, Nikolay: Ugolovnoye Pravo (Ceza Hukuku), Obşaya Çast (Genel Kısım), Moskva 2002, s. 195-196; Veliyev, s. 159.

Zdravomislov, s. 228. 
Rusya Federasyonu doktrininde sübjektif kriteri esas alan ikinci görüş baskındır $^{102}$. Kuznesova'ya göre; doktrinde icra başlangıcının tespiti bakımından objektif kriteri esas alan yazarların, icra bitimi bakımından sübjektif kriteri esas alması anlaşılabilir bir durum değildir ${ }^{103}$. Kanaatimizce bu eleştiri yerinde bir eleştiri olup, eksik-tam teşebbüs ayırımının icra başlangıcının tespitinde olduğu gibi objektif kritere göre yapılması gerekir.

\section{SUÇA TEŞEBBÜSÜN SOSYAL TEHLİKELİLİĞİ}

\section{A. Genel Olarak}

Daha önce de ifade edildiği üzere Rusya Federasyonu ceza hukukunda bir fiilin suç sayılması için ceza kanununda yazılı suç tipine uygun olması yeterli olmayıp, ayrıca "sosyal tehlikeli" olması da gerekmektedir. Çünkü RFCK'nın 14/2. maddesinde, “Bu Kanunda öngörülen herhangi bir fiilin unsurlarını biçimsel olarak içerse bile, az önemli olduğu için sosyal tehlikeli sayılmayan hareket (hareketsizlik) suç sayılmaz" hükmü yer almaktadır.

RFCK'nın 14/2. maddesi, kuşkusuz sadece tamamlanmış suçlara özgü bir hüküm olmayıp, tamamlanmamış suçlarda da uygulanabilmektedir ${ }^{104}$. Dolayısıyla suça teşebbüsün cezalandırılabilmesi, onun sosyal tehlikeli olması şartına bağlıdır.

Suça teşebbüste fiilin sosyal tehlikeli olup olmadığ 1 tespit edilirken, hukuki konunun önem derecesi, meydana gelebilecek zararın değeri ve zararın gerçekleşme ihtimalinin derecesi dikkate alınmalıdır. Eğer teşebbüs edilen suçun hukuki konusu az önemli veya hukuki konuya verilebilecek zararın değeri az ise, bu fiilin RFCK'nın 14/2. maddesi kapsamında değerlendirilmesi ve dolayısıyla suç oluşturmaması mümkündür ${ }^{105}$.

Doktrinde bazı yazarlar hakaret suçu gibi hafif suçlara teşebbüsün RFCK'nın 14/2. maddesi kapsamında değerlendirilmesi gerektiğini ve dola-

102 Kriger/Kurinov/Tkaçevskiy (Ed.), s. 240; Minkovskiy, Genrih/Magomedov, Asbeg/ Revin, Valeriy: Ugolovnoye Pravo Rosii (Rusya Ceza Hukuku), Moskva 1998, s. 51.

103 Kuznesova bu tespitinin ardından eksik-tam teşebbüs ayırımının gereksiz olduğunu savunmaktadır. Yazara göre, eksik-tam teşebbüs ayırımının teorik ve pratik açıdan bir önemi bulunmamaktadır. İcra hareketleri bölünemez ve bu hareketlerin her bir kısmı sonucun gerçekleşmesi için aynı derecede öneme sahiptirler. Ayrıca olayların büyük bir kısmında icra hareketlerini birbirinden ayırmak mümkün değildir. Kişi ya hazırlık hareketlerini ya da suçun icrasını gerçekleştirir. Ayrıca teşebbüste suç faaliyetinin başta veya sonda kesintiye uğramasının bir önemi bulunmamaktadır. Çünkü her iki durumda da suç faaliyeti failin iradesi dışında durdurulmaktadır. (Kuznesova, s. 303-305). 
yısıyla cezalandırılmaması gerektiğini savunmaktadırlar ${ }^{106}$. Rusya Federasyonu Ceza Kanunu'nu iktibas eden Kazakistan Cumhuriyeti Ceza Kanunu'nda bu görüşe yer verilerek, hafif suçlara teşebbüsün cezalandırılmayacağ1 kabul edilmiştir (m.24/4).

RSFSC Yüksek Mahkemesi bir kararında; demiryolu istasyonunda bulunan yük vagonundan karpuz çalmaya çalışırken yakalanan G'nin fiilinin az önemli olması nedeniyle sosyal tehlikeli olmadığına ve dolayısıyla hırsızlık suçuna teşebbüsü oluşturmadığına karar vermiştir. Yüksek Mahkeme bu kararına gerekçe olarak G’nin yanında karpuzları taşımak için özel araç ve gereçler bulunmadığından fiilin önemli bir zarara neden olamayacağını göstermiştir $^{107}$. Rusya Federasyonu Yüksek Mahkemesi bir başka kararında ise 54 ruble değerindeki eşyayı çalmaya teşebbüs eden failin fiilinin az önemli olması sebebiyle sosyal tehlikeli olmadığına ve hırsızlık suçuna teşebbüsün oluşmadığına karar vermiştir ${ }^{108}$.

\section{B. İşlenemez Suç (Elverişsiz Teşebbüs) ve Onun Sosyal Tehlikeliliği}

\section{Genel Olarak}

Bir ceza kanunu hükmünü ihlale yönelmiş olmasına rağmen, "kullanılan aracın elverişsiz olması" veya "suçun maddi konusunun bulunmaması" nedeniyle başarısız kalmaya mahkum bir eyleme işlenemez suç (elverişsiz teşebbüs) denmektedir ${ }^{109}$. Örneğin öldürmek amacıyla bir kimseye, zehir zannederek tebeşir tozu vermek veya canlı zannederek cesede ateş etmek böyledir ${ }^{110}$.

İşlenemez suç, sözde suçtan farklıdır. Sözde suçta failin gerçekleştirmeyi düşündüğü eylem, yasada suç olarak tanımlanmamıştır. İşlenemez suçta ise failin düşündüğü eylem yasada suç olarak tanımlanmıştır. Ancak, aracın elverişsizliği veya maddi konunun yokluğu nedeniyle amaca ulaşılamamaktadir $^{111}$.

\footnotetext{
106 Traynin, s. 33; Tişkeviç, s. 213.

107 Bkz. Yakimenko, Natalya: Osenka Maloznaçitelnosti Deaniya (Eylemin Az Önemliliğinin Değerlendirilmesi), Volgograd 1987, http://ex-jure.ru/law/news.php?newsid=54, E. T.: 03.05.2020.

108 Karar için bkz. 2000 Yılı 9 No.lu Yüksek Mahkeme Bülteni, http://www.supcourt.ru/ files/11233/, E. T.: 03.05.2020.

109 Alacakaptan, Uğur: İşlenemez Suç, Ankara 1968, s. 1-2.

110 Toroslu, s. 265.

111 Centel/Zafer/Çakmut, s. 480.
} 
TCK' da işlenemez suçla ilgili açık bir düzenleme yer almamakla beraber 35/1. maddede, "Kişi, işlemeyi kastettiği bir suçu elverişli hareketlerle doğrudan doğruya icraya başlayıp da elinde olmayan nedenlerle tamamlayamaz ise teşebbüsten dolayı sorumlu tutulur" hükmüne yer verilmiştir. $\mathrm{Bu}$ maddeye göre, teşebbüs için sadece icra hareketlerine başlanılması yeterli olmayıp, "elverişli hareketlerle" icra hareketlerine başlanılmış olması gerekmektedir. Bu yüzden işlenemez suç, Türk ceza hukukunda cezalandırılmamaktadır.

Doktrinde isabetli olarak hareketin elverişli olup olmadığının soyut (ex post) değil, somut olayın koşullarına göre (ex ante) belirlenmesi gerektiği savunulmaktadır ${ }^{12}$. Örneğin tüm mekanizması bozuk olan bir tabanca ile ateş edip insan öldürme suçunu işlemek isteyen failin kullandığ1 araç mutlak surette elverişsiz olduğundan işlenemez suç söz konusudur ve fail teşebbüsten sorumlu olmaz. Buna karşılık, fail aynı bozuk tabancanın kabzası ile öldürmek kastıyla hasmının kafasına defalarca vurmuş, fakat mağdur darbelere rağmen hayatta kalmışsa, araç elverişli olduğu için işlenemez suç yoktur ve fail insan öldürme suçuna teşebbüsten sorumlu olur ${ }^{113}$.

TCK'nın 35/1. maddesinde suça teşebbüs için hareketin sadece elverişli olması yeterli görüldüğünden, aracın elverişli olup, fakat yetersiz kalması durumunda işlenemez suç yoktur. Örneğin mağdura zehirli bir pasta gönderen kimse, dozunun az olmasından dolayı zehir etkisiz kalsa bile, elverişli araç kullanmıştır. Yine içindeki barutun kötü cinsten olması nedeniyle merminin ateş almaması durumunda da araç yetersiz, fakat elverişli olduğu için teşebbüsten ceza verilebilecektir ${ }^{114}$.

\section{Rusya Federasyonu Ceza Hukukunda İşlenemez Suçun Cezalandırılabilirliği}

Rusya Federasyonu doktrininde işlenemez suç, "elverişsiz teşebbüs" olarak adlandırılmaktadır. Ancak bazı yazarlar, teşebbüsün zaten başarısız suç faaliyeti olduğunu ileri sürerek, elverişsizliğin her teşebbüs olayında bulunduğunu ve bu nedenle teşebbüsün elverişli - everişsiz şeklinde ayrılmasının doğru olmadığını iddia etmektedirler ${ }^{115}$.

\footnotetext{
112 Demirbaş, s. 469; Özgenç, s. 482; Koca/Üzülmez, s. 421; Soyaslan, s. 100; Hafizoğulları/Özen, s. 315; İçel/Evik, s. 240; Centel/Zafer/Çakmut, s. 485; Toroslu, s. 263-264; İpekçioğlu, s. 90; Aydın, Devrim: "Suça Teşebbüs", Ankara Üniversitesi Hukuk Fakültesi Dergisi, Cilt 55, Sayı 1, 2006, s. 102.

113 Aydın, s. 102.

114 Hafizoğullar//Özen, s. 315-316.

115 Durmanov, s. 152; Kuznesova, s. 306-307.
} 
Rusya Federasyonu Ceza Kanunu'nda, teşebbüs halinde, failin "elverişli hareketlerle” suçun icrasına başlamış olması gerektiğinden söz edilmemektedir. $\mathrm{Bu}$ nedenle, Türk ceza hukukunun aksine, Rusya Federasyonu ceza hukukunda işlenemez suç halleri kural olarak sosyal tehlikeli sayılmakta ve cezalandırılmaktadır ${ }^{116}$. Doktrinde nisbi-mutlak elverişsiz teşebbüs ayırımı yapılmakta ise de bunun pratik bir öneminin bulunmadığ mutlak elverişsiz teşebbüs ve gerek nisbi elverişsiz teşebbüs hallerinin cezalandırılması gerektiği kabul edilmektedir.

Uygulamada da işlenemez suç hallerinin cezalandırıldığına ilişkin örneklere rastlanmaktadır ${ }^{117}$. Örneğin bir olayda, 16 yaşlarındaki S ve M

\footnotetext{
116 Naumov, s. 308-309.
}

117 RSFSSC Yüksek Mahkemesi Kararı: "S, iş sırasında alkol alarak sarhoş olmuş ve şube müdürü Ş, onu işten atmıştır. S, Ş’den kararını geri almasını rica etmiş, ancak Ş, bu isteği geri çevirmiştir. Bunun üzerine $S$, Ş’yi öldürmeye karar vermiş, evinden dolu tüfeğini alarak Ş’nin bulunduğu işyerine gelmiş ve tüfeğini Ş’ye doğrultarak tetiği çekmiştir. Ancak tüfeğin tetik mekanizmasınin arızalı olması sebebiyle tüfek ateş almamış ve $S$, oradaki işçiler tarafindan yakalanmıştır. Dosya kapsamından anlaşıldı̆̆ı gibi, $S$, tüfeğin arızalı olduğunu bilmemiş ve onunla ateş etmenin mümkün olduğunu sanmıştır. Bu nedenle $S$, insan öldürme suçuna teşebbüsten cezalandırlmalıdır. Çünkü elverişsiz araçlarla suça teşebbüs, failin sosyal tehlikeliliğine işaret eder ve kural olarak ceza sorumluluğuna sebep olur”. (1961-1963 Y1lı RSFSC Yüksek Mahkemesi’nin Genel Kurul, Başkanlık ve Ceza Daireleri Kararlar Dergisi, s. 243-245, (Bkz. İgnatov/ Krasikov (Ed.), s. 132)); Belyaev, Nikolay/Şargorodskiy, Mihail: Kurs Sovetskogo Ugolovnogo Prava (Soyyet Ceza Hukuku Kursu), Obşaya Çast (Genel Kısım), Tom 1 (Cilt 1), Leningrad 1968, http://www.pravo.vuzlib.net/book_z1030.html, E. T.: 18.12.2009, s. 568); RSFSC Yüksek Mahkemesi Karar1: "Elverişsiz konuya (ceset) yönelik insan öldürmeye teşebbüs sosyal tehlikeli sayllır. Olayda Vasilenko yatakhanedeki işçi D'yi öldürdükten sonra, sarhoş olan Orovaynen odaya girmiş ve yerde ölmüş halde yatan D'nin, ölmüş olduğu anlamadan onun alnına baltayla vurmuștur. Adli tıp bilirkişisi D'nin ölümünün kalbine ve akciğerine yapılan bıçak darbelerinden meydana geldiğini tespit etmiştir. D'nin alnindaki balta yarası ise ölümünden sonra meydana gelmiştir. Mahkemenin Orovaynen'in D'yi öldürme kastlyla hareket edip, kastettiğini gerçekleştiremediği yönündeki tespiti doğrudur. Orovaynen'in fiili sosyal tehlikelidir ve cezai sorumluluk gerektirmektedir". (1964-1972 Yılı RSFSC Yüksek Mahkemesi Başkanlık ve Ceza Daireleri Kararlar Dergisi, Moskva 1974, s. 214, (Bkz. Kurçenko, Vyaçeslav: "Problemı Kvalifikasii Prestupleniy v Usloviyah Faktiçeskoy Oşibki (Fiili Hata Şartlarında İşlenen Suçların Değerlendirilmesi Sorunu)", http://www.lawmix.ru/ comm/3646, E. T.: 03.05.2020); Moskova Bölge Mahkemesi'nin 1944 tarih ve 55/44 No.lu kararına konu olan olayda; hasta olan P'nin evini elde etmek isteyen R, onu öldürmek amacıyla kendine doktor süsü vererek P'nin evine gelmiş ve mide ilacı adı altında P'ye kemirgenleri zehirlemek için kullanılan toz bırakmıştır. Ancak bu tozun insan öldürmeye elverişli olmaması nedeniyle ölüm gerçekleşmemiştir. Bu olayda mahkeme R hakkında insan öldürme suçuna teşebbüsten cezaya hükmetmiştir. (Bkz. Kuznesova, s. 314). 
odasını kiraladıkları yaşı N'nin evine sahip olabilmek için "Krısidom" markalı fare zehriyle onu öldürme konusunda anlaşmış ve fare zehrini N'nin yemeğine katmışlardır. Fare zehrinin kalitesinin bozuk olması nedeniyle yemeği yemesine rağmen N'de herhangi bir rahatsızlık meydana gelmemiş, ancak panik yapan $\mathrm{S}$ ve $\mathrm{M}$ polise başvurarak yaptıklarını itiraf etmişlerdir. $\mathrm{Bu}$ olayda, $\mathrm{S}$ ve $\mathrm{M}$ hakkında insan öldürme suçuna teşebbüsten dolay1 hüküm verilmiştir ${ }^{18}$. Bir başka olayda, hazırladığı karışımın çocuk düşürtmeye elverişli olduğunu sanan $\mathrm{E}$, aslında çocuk düşürmeye elverişli olmayan bu karışımı iğneyle mağdurlara enjekte etmiş ve $\mathrm{E}$ hakkında çocuk düşürtme suçuna teşebbüsten ceza verilmiştir ${ }^{119}$.

Rusya Federasyonu Yüksek Mahkemesi'nin Uyuşturucu Maddelerle İlgili Suçlara İlişkin Mahkeme Uygulamaları Hakkındaki 27.05.1998 tarih ve 9 No.lu Genel Kurul kararında da "Uyuşturucu madde satın almak isteyen kişileri kandırmak suretiyle, onlara uyuşturucu madde adı altında aslında uyuşturucu özelliği bulunmayan maddeleri satan kişinin fiilini dolandırıcıllk olarak değerlendirmek gerekir. Bu tür durumlarda bu maddeleri satın alan kişilerin fiili ise kanuni şartların varlığı halinde, yasadışı uyuşturucu madde satın alma suçuna teşebbüs olarak değerlendirilebilir" ${ }^{\prime 20}$ denilmek suretiyle elverişsiz teşebbüs hallerinin cezalandırılması gerektiğine işaret edilmiştir.

Rusya Federasyonu ceza hukukunda sözde suç cezalandırılmamaktadır. Ancak doktrinde ve uygulamada sözde suçun sadece hukuki hatadan kaynaklanabileceği kabul edilmiş olduğundan, fiili hataya dayanan sözde suç halleri, elverişsiz teşebbüs kapsamında değerlendirilmekte ve teşebbüs hükümlerine göre cezalandırılmaktadır. Buna göre, örneğin gerçekte sahte olmayan parayı, sahte olduğunu sanarak tedavüle koyan kişi, sahte parayı tedavüle koyma suçuna teşebbüsten cezalandırılmalıdır ${ }^{121}$. Yine failin kamu görevlisi olduğunu sandığı, fakat gerçekte kamu görevlisi olmayan bir kimseye rüşvet teklif etmesi durumunda da yapılan hareketin rüşvet suçuna teşebbüs sayılması gerekir ${ }^{122}$.

Rusya Federasyonu Yüksek Mahkemesi'nin Rüşvet Suçlarına İlişsin Mahkeme Uygulamaları Hakkındaki 10.02.2000 tarih ve 6 No.lu Genel

118 Bkz. Kriger/Kuznesova/Tkaçevkiy (Ed.), s. 171; Bir başka olayda, patlayıcının patlamaması üzerine bankayı soyamayan failin hareketi, yağma suçuna teşebbüs olarak değerlendirilmiştir. (Bkz. Kuznesova/Tyajkova (Ed.), s. 375).

119 Moskova Bölge Mahkemesi'nin 24.01.1952 tarih ve 22/59 No.lu kararı için bkz. Kuznesova, s. 313-314.

120 http://www.supcourt.ru/documents/own/7787/, E. T.: 03.05.2020.

$121 \operatorname{Rar} 0 \mathrm{~g}$ (Ed.), s. 157.

122 Kriger/Kuznesova/Tkaçevkiy (Ed.), s. 170-171; Zagorodnikov, s. 121. 
Kurul kararında da "Eğer kişi, rüşvet için görevli memura iletecekmiş gibi bir kimseden para veya değerli eşya almış; ancak gerçekte böyle bir niyeti bulunmayan bu kişi, bunları kendisi için almışsa, onun yaptığını dolandırıcılık olarak değerlendirmek gerekir. Bu durumlarda rüşvet verdiğini sanarak dolandırıcıya para veya değerli eşyaları veren kişinin hareketleri ise rüşvet verme suçuna teşebbüs olarak değerlendirilmelidir. Bu olaylarda rüşvet konusu para veya değerli eşyanın teslim edileceği görevli kişinin isminin taraflar arasında zikredilmiş olması da önemli değildir." ${ }^{23}$ denilmek suretiyle bu hususa işaret edilmiştir.

İşlenemez suç halleri kural olarak cezalandırılmakla birlikte, bazı istisnai fiiller RFCK'nın 14/2. maddesi kapsamında değerlendirilmekte ve cezalandırılmamaktadır ${ }^{124}$. Bunları beddua, lanetleme, ölüm büyüsü yapma gibi az önemli olması sebebiyle sosyal açıdan tehlikeli sayılmayan hareketler oluşturmaktadır ${ }^{125}$. Bu husus Yüksek Mahkemenin bir kararında da "Elverişsiz araçlarla suça teşebbüs, failin sosyal tehlikeliliğine işaret eder ve kural olarak ceza sorumluluğuna sebep olur. Ancak batıl inançlart veya cahilliği nedeniyle doğaüstü güçlerle bir kimseye zarar vermeye çalışan failin hareketi, az önemli olması sebebiyle sosyal tehlikeli sayllmadiğ için ve bu durum sadece failin suç işleme kastının belirlenmesi (düşünce aşaması) olduğundan ceza sorumluluğuna sebep olamaz." şeklinde ifade edilmiştir ${ }^{126}$.

Sosyal tehlikeli olan işlenemez suç halleri, cezalandırılmakla birlikte, mahkeme tarafından seçimlik cezaların seçimi ve cezanın alt ve üst sınırı arasındaki süre veya miktarın belirlenmesi sırasında ceza sorumluluğunu azaltan neden olarak dikkate alınmalıdır ${ }^{127}$. Bu husus, RFCK'nın 66/1. maddesinde "Tamamlanmamış suç için cezanın belirlenmesi sırasında suçun tamamlanmamasına neden olan sebepler dikkate alınır" şeklinde hükme bağlanmıştır. Yine RFCK'nın 60/3. maddesine göre, mahkeme cezanın belirlenmesi sırasında suçun sosyal tehlikelilik derecesini dikkate almak durumundadır. Kuşkusuz işlenemez suçta fiilin sosyal tehlikeliliği daha azdır.

Kanaatimizce; Türk ceza hukukunda olduğu gibi, Rusya Federasyonu ceza hukukunda da mutlak elverişsiz teşebbüs (aracın veya konunun mutlak

\footnotetext{
$123 \mathrm{http}: / /$ www.supcourt.ru/documents/own/8360/, E. T.: 03.05.2020; SSCB Yüksek Mahkemesi'nin 30.03.1990 tarih ve 3 No.lu Genel Kurul kararı ile 23.09.1977 tarih ve 16 No.lu Genel Kurul kararı da aynı yöndedir. (Bkz. Veliyev, s. 162; Kriger/ Kuznesova/Tkaçevkiy (Ed.), s. 241).

124 Kozaçenko/Neznamova (Ed.), s. 224.

125 Naumov, s. 309.

1261963 Yılı 4 No.lu Yüksek Mahkeme Bülteni, (Bkz. Belyaev/Şargorodskiy, s. 568).

127 Vetrov, s. 197.
} 
elverişsizliği nedeniyle işlenemez suç) hallerinde failin cezalandırılmaması gerekir. Çünkü RFCK'nın 30/3. maddesinde, "doğrudan doğruya suçun işlenmesine yönelmiş hareketler" suça teşebbüs sayılmaktadır. Daha önce de ifade ettiğimiz gibi, bu düzenlemeye uygun olarak Rusya Federasyonu doktrininde icra hareketlerine başlama bakımından hukuki konunun "doğrudan ve somut" bir tehlikeye maruz kalması aranmaktadır. Mutlak elverişsiz teşebbüs hallerinde hukuki konunun "doğrudan ve somut" bir tehlikeye maruz kaldığını söylemek mümkün değildir. Bu nedenle, her ne kadar, RFCK'nın 30/3. maddesinde teşebbüs (icra) hareketinin "elverişli olması" aranmamış ise de mutlak elverişsiz teşebbüs hallerinde doğrudan doğruya icraya başlandığından söz edilemez ve bu hareketlerin teşebbüs olarak cezalandırılmaması gerekir. Yine bu tür hareketler elverişsiz olması nedeniyle suçun işlenmesine ortam yaratamadığına göre, bu hareketlerin suça hazırlık olarak da cezalandırılmaması gerekir.

\section{SUÇA TEŞEBBÜSÜN CEZASI}

Tamamlanmamış suç için ceza sorumluluğunu düzenleyen RFCK'nın 66. maddesine göre; "1.Tamamlanmamış suç için cezanın belirlenmesi sırasinda suçun tamamlanmamasına neden olan sebepler dikkate alınır.

3. Suça teşebbüsten dolayı cezanın süresi veya miktarı, bu Kanunun özel kısmının ilgili maddesinde tamamlanmış suç için öngörülen en ağır ceza türünün üst sinırındaki süre veya miktarın dörtte üçünden fazla olamaz”.

Aynı maddenin 4. fikrasına göre ise, “... suça teşebbüsten dolayı ölüm cezasina ${ }^{128}$ veya müebbet hapis cezasina hükmedilemez".

Görüldüğü gibi, Rusya Federasyonu Ceza Kanunu'nda suça teşebbüs halinde ceza indirimi öngörülmüştür. Ancak, bu indirim tam anlamıyla bir "zorunlu ceza indirimi" değil, bir tür "cezayı üst sinırdan belirleme yasağg" şeklinde ortaya çıkmaktadır. Örneğin kasten öldürme suçunun basit şeklinin cezas1, 6 seneden 15 seneye kadar hapis cezasıdır (RFCK m.105/1). Bu durumda, kasten öldürme suçuna teşebbüsün cezası, 6 seneden 11,25 seneye kadar hapis cezası olmaktadır. Dolayısıyla suça teşebbüs için öngörülen

128 Rusya Federasyonu Anayasası'na göre, kanunda açıkça belirtilmek şartıyla ölüm cezası sadece hayata karşı işlenen suçlar karşıllğında uygulanabilir (m.20/2). Ancak Rusya Federasyonu Anayasa Mahkemesi 19.11.2009 tarih ve 1344-O-R No.lu kararında ölüm cezasının Rusya Federasyonu'nun hiçbir bölgesinde uygulanamayacağına karar vermiştir. (Ayrıntılı bilgi için bkz. Hüseyinoğlu, Emin: "Rusya Federasyonu Ceza Hukukunda Ölüm Cezası", Selçuk Üniversitesi Hukuk Fakültesi Dergisi, Cilt 28, Sayı 2, 2020, s. 427-444). 
indirim, suç için öngörülen cezanın alt ve üst sınırı arasında belirlenecek sonuç ceza üzerinden yapılmamaktadır. Yani 66. madde, suça hazırlıkta, tamamlanmış suç için öngörülen cezanın alt sınırından daha az ceza verilmesini öngörmüş değildir ${ }^{129}$.

Kuşkusuz mahkeme diğer suçlardan cezaya hükmederken dikkate alması gereken hususları teşebbüsten dolayı cezaya hükmederken de dikkate alacaktır. RFCK'nın 60/3. maddesine göre; “Cezanın belirlenmesi sırasında suçun niteliği ve sosyal tehlikelilik derecesi ile failin kişiliği; cezayı hafifletici ve ağırlaştırıcı nedenler, cezanın failin uslah olmasına, failin ve onun ailesinin hayatına etkisi dikkate alınmalıdır".

\section{GÖNÜLLÜ VAZGEÇME}

\section{A. Genel Olarak}

Failin doğrudan doğruya suçun işlenmesine yönelik olan veya suçun işlenmesine ortam yaratan kasıtlı hareketleri failin elinde olmayan nedenlerle tamamlanmadığında, fail suça teşebbüs veya suça hazırlıktan sorumlu olur. Fakat bazı durumlarda fail kendi isteğiyle hazırlık hareketlerine veya icra hareketlerine son vererek suçun tamamlanmamasını sağlayabilir. Bu duruma "gönüllü vazgeçme" denir.

Rusya Federasyonu doktrininde baskın görüş, gönüllü vazgeçmenin suçun sosyal tehlikelilik özelliğini ortadan kaldırdığını ve bu nedenle gönüllü vazgeçme halinde, işlenen fiilin suç sayılmayacağını savunmak$\operatorname{tad}^{130}{ }^{130}$. Ancak gönüllü vazgeçmenin meşru savunma ve zorunluluk hali gibi

129 Türk Ceza Kanunu'ndan farklı olarak Rusya Federasyonu Ceza Kanunu'na göre, herhangi bir suçtan dolayı cezanın belirlenmesi sırasında faile işlediği suçu düzenleyen madde hükmünde öngörülen cezadan daha ağır ceza verilmesi mümkün değildir. Yine kural olarak faile işlediği suçu düzenleyen madde hükmünde öngörülen cezadan daha hafif ceza verilmesi de mümkün değildir (RFCK m.60). Yani hakim cezayı hafifletici ve ağırlaştırıcı nedenleri, sadece kanunun özel kısmında o suç için öngörülen cezanın alt ve üst sınırı arasındaki sonuç cezayı belirleme bakımından dikkate alabilmektedir. Sözü edilen bu kuralın istisnasını RFCK'nın 64. maddesi oluşturmaktadır. Bütün suçlarda uygulanabilen ve "takdiri hafifletici nedenler" olarak adlandırabileceğimiz bu düzenlemeye göre; failin amaç ve saiki, suçtaki rolü, suçtan önceki ve sonraki davranışları, suçun sosyal tehlikeliliğini önemli derecede azaltan diğer nedenler, iştirak halinde işlenen suçlarda suçun ortaya çıkmasına etkin yardımda bulunma ve benzeri nedenlerin varlığı halinde, mahkeme suç için öngörülen cezanın alt sınırından daha hafif cezaya hükmedebilir veya zorunlu olan ek cezalara hükmetmeyebilir.

130 Kuznesova/Tyajkova (Ed.), s. 376, 378; Piontkovskiy, s. 433-434; Ter-Akopov, s. 40; Kudryavsev, Vladimir/Naumov, Anatoliy (Ed.): Uçebnik Ugolovnogo Prava (Ceza Hukuku Ders Kitabı), Obşaya Çast (Genel Kısım), Moskva 1996, s. 179; Belyaev/ 
hukuka uygunluk nedenlerinden farklı olduğu da ileri sürülmektedir. Buna göre; meşru savunma ve zorunluluk halinde fiil başından beri sosyal faydalı iken, gönüllü vazgeçme halinde failin ve fiilin sosyal tehlikeliliği sona ermektedir. Gönüllü vazgeçme sosyal hayata olumlu bir şey katmamaktadır. Gönüllü vazgeçme halinde sadece hareketin sosyal tehlikeliliği ortadan kalkmaktadır ${ }^{131}$.

Kanaatimizce gönüllü vazgeçmenin suçu ortadan kaldırdığını ileri süren bu görüşler isabetli değildir. Çünkü eğer gönüllü vazgeçmenin suçu ortadan kaldırdığı kabul edilirse, iştirak halinde işlenen suçlarda, failin suçun işlenmesinden vazgeçmesi durumunda, diğer suç ortaklarının suça hazırlık veya suça teşebbüsten sorumlu tutulması mümkün olamaz. Oysa Rusya Federasyonu ceza hukukunda iştirak halinde işlenen suçlarda ${ }^{132}$, sadece gönüllü vazgeçen kişinin gönüllü vazgeçme hükümlerinden yararlanabileceği kabul edilmektedir ${ }^{133}$. Bizce gönüllü vazgeçme bir kişisel cezasızlık nedeni olup, suçu ortadan kaldıran neden değildir ${ }^{134}$. Türk doktrininde de gönüllü vazgeçmenin bir kişisel cezasızlık nedeni olduğu ve cezalandırılmama nedeninin suç politikası görüşleriyle açıklanabileceği kabul edilmektedir ${ }^{135}$.

Eski 1960 tarihli RSFSCCK'da gönüllü vazgeçme halinde, faile suça hazırlık veya suça teşebbüsten dolayı ceza verilmeyeceği hükme bağlanmakla birlikte, gönüllü vazgeçmeden neyin anlaşılması gerektiği açıklanmamıştı. Buna karşıllı yürürlükteki 1996 tarihli RFCK'da gönüllü vazgeçme açık bir şekilde tanımlanmıştır.

"Suçu işlemekten gönüllü vazgeçme" başlıklı RFCK'nın 31. maddesine göre; Yürürlükteki 1996 tarihli RFCK'da gönüllü vazgeçme açık bir şekilde tanımlanmıştır. "Suçu işlemekten gönüllü vazgeçme" başlıklı RFCK'nın 31. maddesine göre; "1. Suçu tamamlama imkanına sahip olduğunun bilincinde

Şargorodskiy, s. 577; Durmanov, s. 189, 191; Tagansev, s. 168; Tişkeviç, s. 217, 220221.

131 Durmanov, s. 192; Kuznesova, s. 396.

132 Suça iştirak konusunda ayrıntılı bilgi için bkz. Hüseyinoğlu, Emin: "Rusya Federasyonu Ceza Hukukunda Suça İştirak”, Ankara Üniversitesi Hukuk Fakültesi Dergisi, Cilt 67, Say1 4, 2019, s. 735-782.

133 Naumov, s. 345-346; Rarog (Ed.), s. 242.

134 Rusya Federasyonu doktrininde gönüllü vazgeçmenin suçun varlığını değil, failin sosyal tehlikeliliğini kaldıran kişisel cezasızlık nedeni olduğunu savunan yazarlar da bulunmaktadır. (Bkz. Durmanov, s. 191).

135 Dönmezer/Erman, s. 439; Öztürk/Erdem, s. 326; Soyaslan, s. 120; Sözüer, s. 240; Özgenç, s. 490; İçel/Evik, s. 257; Demirbaş, s. 461; Centel/Zafer/Çakmut, s. 475; Koca/Üzülmez, s. 430. 
olan kişi tarafindan suça hazırlık hareketlerinin veya doğrudan doğruya suçun işlenmesine yönelmiş hareketlerin (hareketsizlik) durdurulması gönüllü vazgeçme sayllır.

2. Suçu tamamlamaktan gönüllü ve kesin olarak vazgeçen kişi, ceza sorumluluğu taşımaz.

3. Suçu tamamlamaktan gönüllü vazgeçen kişi, sadece işlediği fiil esasen başka bir suç oluşturduğunda ceza sorumluluğu taşır”.

\section{B. Gönüllü Vazgeçmenin Unsurları}

Gönüllü vazgeçmenin gönüllülük, kesinlik, suçun tamamlanabileceği bilinci ve suçun tamamlanmamış olması şeklinde dört şartı bulunmaktadır. Yani kastettiği suçu işleyebileceğine somut engel bulunmadığının bilincinde olmasına rağmen, failin kendiliğinden ve kesin olarak hazırlık veya icra hareketlerine son vermesi gönüllü vazgeçme sayılır ${ }^{136}$.

\section{Gönüllülükk}

Vazgeçmenin gönüllü sayılabilmesi için, bunun diş nedenlerden değil, iç nedenlerden ötürü meydana gelmesi gerekmektedir ${ }^{137}$. Vazgeçme gönüllü olduktan sonra bunun mağdura acıma, pişmanlık, cezalandırılma korkusu, rezil olma duygusu gibi hangi sebeplerden ötürü meydana geldiği önemli değildir $^{138}$. Gönüllü vazgeçmenin başkalarının teşviki (akraba, dost, eş nasihati gibi) sonucu meydana gelmesi de mümkündür ${ }^{139}$. Ancak üçüncü kişilerin failin suçu işlemesine izin vermeyeceklerini veya onu ihbar edeceklerini söylemeleri üzerine failin suçu işlemekten vazgeçmesi gönüllü vazgeçme sayılmaz $^{140}$.

Failin bazı engellerle karşılaşması sebebiyle suçu tamamlamaktan vazgeçmesi gönüllü vazgeçme sayılmaz ${ }^{141}$. Örneğin mağdurun direnmesi, polis

\footnotetext{
136 Semenderov, s. 341.

137 Rusya Federasyonu Yüksek Mahkemesi'nin 04.06.2003 Tarihli Kararı: “Elinde olmayan nedenlerle (bekçinin kendisini fark etmesi nedeniyle) suçu tamamlamaması, İsayev'in hareketlerinde suç unsurunun bulunmadı̆̆ını göstermez. Çünkü mă̆azada değerli mallar bulunmaktaydı ve sanık bunları çalmaya teşebbüs etmiştir”. (2003 Y1lı 12 No.lu Yüksek Mahkeme Bülteni, (Bkz. Kudryavsev, Vladimir/Luneev, Viktor/Naumov, Anatoliy (Ed.): Ugolovnoye Pravo Rosii (Rusya Ceza Hukuku), Obşaya Çast (Genel Kisim), Moskva 2006, s. 244)).

138 Magomedov, s. 60.

139 Vetrov, s. 198.

140 Durmanov, s. 195.

141 Kudryavsev/Luneev/Naumov (Ed.), s. 247.
} 
müdahalesi veya bir tanıkla karşılaşması sebebiyle suçu işlemekten vazgeçen kişi, gönüllü vazgeçmeden yararlanmaz ${ }^{142}$. Ortaya çıkan engellerin suçun işlenmesini imkansız hale getirmeyip, suçun işlenmesini zorlaştırması halinde de suçu işlemekten vazgeçen kişi gönüllü vazgeçmeden yararlanmaz ${ }^{143}$. Örneğin, evin kapısını açmayı başaran hırsız, ikinci bir kapıyla karşılaşır ve bunun üzerine suçu işlemekten vazgeçerse, gönüllü vazgeçme hükümleri uygulanmaz ${ }^{144}$.

Adli makamların işlenecek suçtan haberdar olması nedeniyle failin suçu işlemekten vazgeçmesi gönüllü vazgeçme sayılmaz ${ }^{145}$. Suçun maddi konusunun failin aradığı özellikte olmaması nedeniyle, failin hareketlerine son

142 İvanov, Nikita: Ugolovnoye Pravo Rosii (Rusya Ceza Hukuku), Obşaya i Osobennaya Çast (Genel ve Özel Kısım), Moskva 2003, s. 252; SSCB Yüksek Mahkemesi'nin 19.09.1974 Tarihli Genel Kurul Kararı: "Şampurov ve Andreyev şu şartlarda reşit olmayan V'ye cinsel saldırıda bulunmaya teşebbüsten mahkûm olmuşlardır: '22.11.1973 tarihinde Krasnoyarsk şehrinde, işten dönen $V$ ile sokakta karşllaşan Şampurov ve Andreyev ona cinsel saldirda bulunmaya karar vermişlerdir. Bu amaçla onlar V'yi yakınlardaki boş daireye sürüklemiş, üstünü çıkarmaya çalışmış, ancak mağdure onlara direnmiştir. V, ceketinden çıkardiğı makasla Şampurov'a vurmuş ve bağırarak ayaklarıyla saldirganları itmiştir. Bu sırada birileri dairenin kapısına vurmuş, Şampurov pencereye doğru firlamıs ve camı kırarak Andreyev'e oradan ayrlmaların teklif etmiştir. Kaplya yaklaşan Andreyev merdiven sahanlığında kimsenin olmadiğından emin olduktan sonra, tekrar V'ye saldırmış, onu darp etmiş ve ölümle tehdit etmişstir. Ancak yine de mağdurun bağırma sesini komşuların duyacă̆ından endişe eden Şampurov ve Andreyev pencereden atlayarak kaçmışlardır'. Kapıya vurulması dairede olup bitenlerin komşuların dikkatini çektiğini ve dolaylsıyla sanıkların tespit edilmeleri ve yakalanmaları için bir tehlikenin ortaya çıktı̆̆ını göstermektedir. Kaldı ki, mağdur da yardım çağırarak bağırmaya devam etmiştir. Belirtilen nedenler, sanıkların cinsel saldırı giriş̧imini tamamlamaktan gönüllü vazgeçtiklerini göstermez". (http://projects.innovbusiness.ru/ pravo/DocumShow_DocumID_33329.html, E. T.: 07.05.2011).

143 Sank-Peterspurg Şehir Mahkemesi'nin 17.03.1998 Tarihli Kararı: "Sanık Abramov hırsızlık amacıyla mağdur Bogun'un oturduğu evin kapı kilidini kırmış, ancak bu sırada kapıda 'güvenlik alarmı devrededir' tabelasını görünce olay yerini terk etmistitir. Olayda gönüllü vazgeçme hükümleri uygulanamaz ve Abramov hakkında mala zarar verme suçundan ve hırsızlık suçuna teşebbüsten ceza verilmesi gerekir". (http://www.law.edu.ru/ judicial/judicial.asp?judicialID=1124774, E. T.: 22.01.2010); SSCB Yüksek Mahkemesi 28.05.1941 tarihli kararında; mağdure R'nin bağırması üzerine, yakındaki tarlada bir kişinin çalıştı̆ıını bilen O'nun cinsel saldırıdan vazgeçerek kaçmasında gönüllü vazgeçmenin bulunmadığına karar vermiştir. (Bkz. Durmanov, s. 194-195).

İvanov, s. 253.

145 Zdravomıslov, s. 235; Moskova Şehir Mahkemesi 1951 tarih ve 2-03 No.lu kararında; maskeli ve silahlı sanıkların soygun amacıyla mağazaya girdikten sonra, mağaza müdürünün sanıklardan birini tanıdığını ve polis çağıracağını söylemesi üzerine sanıkların suçtan vazgeçmesinde gönüllü vazgeçmenin bulunmadığına karar vermiştir. (Bkz. Kuznesova, s. 378). 
vermesi de gönüllü vazgeçme kapsamında değerlendirilmez. SSCB Yüksek Mahkemesi 1943 tarihli kararında, yiyecek çalmak amacıyla vagonun kapısını açan sanıkların vagonda sadece manifatura bulunması nedeniyle, hiçbir şey almadıkları olayda, gönüllü vazgeçme hükümlerinin uygulanamayacağını belirtmiştir ${ }^{146}$.

Failin isnat yeteneğinin azalması veya ortadan kalkması nedeniyle suçu tamamlayamaması durumları gönüllü vazgeçme olarak değerlendirilmez. Örneğin aşırı sarhoş olduğu için hırsızlık veya cinsel saldırı suçunun icra hareketlerine başlayıp da suçu tamamlayamayan kişi, suça teşebbüsten dolay1 sorumlu olur ${ }^{147}$.

\section{Suçun Tamamlanabileceği Bilinci}

Aslında suçun işlenmesine engel bulunmadığı halde, fail hata sonucu bazı engellerin bulunduğunu sanarak suçu işlemekten vazgeçerse, bu durum gönüllü vazgeçme olarak değerlendirilmez ${ }^{148}$. Çünkü gönüllü vazgeçmede failin suçu tamamlayabileceğinin bilincinde olması da gerekmektedir ${ }^{149}$. Örneğin hırsızlık için eve giren fail, koridordaki vazonun yere düşmesinin çıkardığg gürültü nedeniyle ev sahibinin evde olduğunu sanarak olay yerini terk ederse, gönüllü vazgeçme hükümlerinden yararlanmaz ${ }^{150}$.

Aslında suçun işlenmesine engel bulunduğu halde, fail hata sonucu herhangi bir engelin bulunmadığını sanmış ve suçu işlemekten vazgeçmişse gönüllü vazgeçme hükümlerinden yararlanır. Örneğin fail dolu olduğunu sandığ1, fakat gerçekte boş olan tabancasını mağdura doğrulttuktan sonra, mağdura acıyarak tetiği çekmekten vazgeçerse, gönüllü vazgeçmeden yararlanır ${ }^{151}$. Başka bir ifadeyle, elverişsiz teşebbüs hallerinde de gönüllü vazgeçmeden söz edilebilir.

\footnotetext{
146 Bkz. Kuznesova, s. 377.

147 Bir olayda, uyuşturucu bağımlısı olan $\mathrm{M}$, kendisiyle görüşmeyi reddeden sevgilisini öldürmek için yüksek miktarda uyuşturucu alarak onun evine gelmiş, evde mağdurla tartışmaya başlamış, elindeki bıçağı sallayarak mağduru öldürmekle tehdit etmiş, ancak bu sırada almış olduğu uyuşturucunun etkisiyle şoka girerek bayılmıştır. Bunun üzerine mağdur polis çağırmış ve $\mathrm{M}$ yakalanmıştır. Bu olayda $\mathrm{M}$, uyuşturucu kullanma ve insan öldürme suçuna teşebbüsten mahkûm olmuştur. (Bkz. Kuznesova/Tyajkova (Ed.), s. 371).

148 Kudryavsev/Luneev/Naumov (Ed.), s. 247.

149 Zagorodnikov, s. 122.

150 Ter-Akopov, s. 52.

151 Ter-Akopov, s. 52-53.
} 


\section{Kesinlik}

Gönüllü vazgeçme hükümlerinin uygulanabilmesi için failin suçun işlenmesinden geçici olarak değil kesin ve şartsız olarak vazgeçmesi gerekir $^{152}$. Failin daha iyi hazırlık yapıp, suçu daha sonra işlemek amacıyla hareketlerini durdurması gönüllü vazgeçme sayılmaz ${ }^{153}$. Örneğin depodan hırsızlık yapmak için depo bekçisiyle anlaşan failin, olay sırasında deponun bulunduğu yerde başka bekçiyi görmesi üzerine hırsızlık suçunu işlemekten vazgeçmesi, gönüllü vazgeçme sayılmaz ${ }^{154}$. Yine bir tanıkla karşılaştığ 1 için, failin daha uygun bir zamanda işlemek üzere hırsızlık suçundan vazgeçmesi, gönüllü vazgeçme değildir ${ }^{155}$.

Ancak kuşkusuz, failin somut suçu kesin olarak işlemekten vazgeçmesi yeterli olup, bu vazgeçmenin bir daha hiç suç işlememek şeklinde olması gerekmez $^{156}$. Hatta failin kastettiği suçu işlemekten vazgeçerek başka bir suçu işlemesi durumu da failin kastettiği suç bakımından gönüllü vazgeçme sayılabilir. Örneğin mağduru öldürmek isteyen fail, mağdura tabancasını doğrulttuktan sonra öldürme niyetinden vazgeçip tehdit ederek mağdurun cüzdanını alırsa, sadece yağma suçundan sorumlu olur; fakat gönüllü vazgeçme nedeniyle insan öldürme suçuna teşebbüsten sorumlu olmaz ${ }^{157}$.

\section{Suçun Tamamlanmamış Olması}

Gönüllü vazgeçme sadece suça teşebbüs veya suça hazırlıktan dolay1 failin sorumluluğunu kaldırdığından, gönüllü vazgeçmeye ilişkin hükümler, sadece suçun tamamlanmamış olduğu hallerde uygulanabilir.

152 Ter-Akopov, s. 54.

153 Semenderov, s. 342; İvanov, s. 253.

154 Kuznesova/Tyajkova (Ed.), s. 378.

155 İvanov, s. 253.

156 Kriger/Kuznesova/Tkaçevkiy (Ed.), s. 172.

157 Ter-Akopov, s. 41; Rusya Federasyonu Yüksek Mahkemesi Kararı: "Olayda sanıklar Beyman, Belobabka, Butakov ve Putilin, evine girdikleri mağdur Kostyuk'u döverek ve tehdit ederek ondan para ve otomobilinin anahtarın talep etmislerdir. Ancak mağdurun otomobilin anahtarının o esnada evde bulunmayan karısında olmasinı söylemesi üzerine, mağdurun bu söylemine inanan sanıklar, evdeki değerli eşyalarl alarak olay yerini terk etmişlerdir. Olayda sanıkların mağdurun ceplerini kontrol etmemeleri, aslında evin bahçesinde olan otomobili başka yöntemlerle de çalıştırabilecekleri halde bunu yapmamaları dikkate alındı̆̆ında, yasadışı otomobil kaçırma suçu (RFCK m.166) bakımından sanıklar hakkında gönüllü vazgeçme hükümlerinin uygulanması gerekir". (2004 Y1lı 3 No.lu Yüksek Mahkeme Bülteni, http://www.supcourt.ru/files/10052/, E. T.: 03.05.2020). 
Rusya Federasyonu doktrininde ve uygulamasında failin suça teşebbüse yönelik ilk hareketi başarısız olduktan sonra, failin aynı hareketi tekrarlamaktan vazgeçmesi durumu, gönüllü vazgeçme olarak kabul edilmemektedir. Başka bir ifadeyle, teşebbüs hareketinin tekrarlanmasından vazgeçme, gerçekleşmiş olan teşebbüsü ortadan kaldırmaz ${ }^{158}$. Örneğin failin mağduru öldürmek amacıyla ateş ettiği mermi mağdura isabet etmez ve fail tekrar ateş etmekten vazgeçerse, bu durum gönüllü vazgeçme olarak değerlendiril$m e z^{159}$. Yine failin mağduru öldürmek amacıyla ateş ettiği mermi mağduru yaraladıktan sonra, failin pişman olarak tekrar ateş etmemesi durumu da gönüllü vazgeçme sayılmaz ${ }^{160}$. Aynı şekilde failin mağduru öldürmek amacıyla ateş ettiği mermi mağduru yaraladıktan sonra, pişman olan failin mağduru hastaneye kaldırıp yaralı olarak kurtarması durumu da gönüllü vazgeçme değildir. Ancak bu durum cezayı hafifletici etkin pişmanlık olarak değerlendirilir ${ }^{161}$. Çünkü RFCK'nın 61. maddesinde, "suçun işlenmesinden hemen sonra mă̆dura tıbbi veya başka şekilde yardımda bulunma" cezayı hafifletici neden olarak düzenlenmiştir.

Doktrinde ve uygulamada yukarıda verilen örneklerde gönüllü vazgeçmenin uygulanmaması gerektiği konusunda görüş birliği bulunmakla birlikte, yine de tam teşebbüs aşamasında gönüllü vazgeçmenin uygulanıp uygulanmayacağı tartışmalıdır.

$\mathrm{Bu}$ konudaki birinci görüşe göre, istisnai durumlarda tam teşebbüs aşamasında gönüllü vazgeçme söz konusu olabilir. Buna göre; failin gerçekleştirdiği hareket ile netice arasında belli bir zaman aralığının bulunduğu hallerde, fail illiyet bağının gidişatını denetleyebiliyor ve ona etki edebiliyorsa tam teşebbüs aşamasında da gönüllü vazgeçme mümkündür. Ancak bu durumda gönüllü vazgeçmenin aktif davranışlarla yapılması gerekir ${ }^{162}$. Örneğin evde yangın çıkaran failin, birkaç dakika sonra dönüp ateşi söndürmesi

\footnotetext{
158 Piontkovskiy, s. 438.

159 Kozaçenko/Neznamova, s. 226. RSFSC Yüksek Mahkemesi'nin 1970 tarihli Genel Kurul kararında da suça teşebbüs halinde, ilk hareket başarısız olduktan sonra, failin aynı hareketi tekrarlamaktan vazgeçmesinin gönüllü vazgeçme sayılamayacağı belirtilmiștir. (1970 Yılı 2 No.lu Yüksek Mahkeme Bülteni, (Bkz. Grişaev/Zdravomıslov, s. 212)).

160 Naumov, s. 313.

161 Kuznesova/Tyajkova (Ed.), s. 379; Kudryavsev/Naumov (Ed.), s. 179.

162 Naumov, s. 314; Vetrov, Nikolay/Lyapunov, Yuriy: Ugolovnoye Pravo (Ceza Hukuku), Çast Obşaya-Çast Osobennaya (Genel Kısım-Özel Kısım), Moskva 2007, s. 145; Kozaçenko/Neznamova (Ed.), s. 226-227; İvanov, s. 254; Revin, 218; Grişaev/ Zdravomislov, s. 213-214; Piontkovskiy, s. 435-436; Ter-Akopov, s. 44; Solopanov, s. 95-96; Kriger/Kuznesova/Tkaçevkiy (Ed.), s. 172.
} 
gönüllü vazgeçme sayılır ${ }^{163}$. Yine mağdurun otomobiline patlayıcı düzenek yerleştiren fail, mağdur olay yerine gelmeden pişman olarak patlayıcıyı etkisiz hale getirirse, gönüllü vazgeçmeden yararlanır ${ }^{164}$. Ancak bu görüşü savunan yazarlar, failin mağdura zehir içirdikten sonra, panzehir vererek veya doktor çağırarak mağdurun ölmesini engellemesi durumunda gönüllü vazgeçmenin uygulanıp uygulanmayacağı konusunda farklı düşünmektedirler. Bazı yazarlar bu durumda da gönüllü vazgeçmenin uygulanması gerektiğini savunmaktayken ${ }^{165}$; diğer bazı yazarlar ise bu durumda gönüllü vazgeçme değil, etkin pişmanlık hükümlerinin uygulanması gerektiğini savunmaktadırlar ${ }^{166}$. Naumov'a göre; burada failin illiyet bağını tamamen denetleyebildiği söylenemez. Çünkü burada ölüm neticesinin meydana gelip gelmemesi sadece failin iradesine bağlı değildir; mağdur da bu panzehiri kabul etmeme imkanına sahiptir. Örneğin amansız bir hastalığa yakalanmış olduğu için mağdur zaten yaşamak istemiyor olabiliir ${ }^{167}$. Durmanov'a göre de bu örnekte neticenin gerçekleşmesi failin iradesine değil, mağdurun vücut direnci, doktorun zamanında müdahale edip etmeyeceği gibi nedenlere bağ${ }_{1} d_{1 ı}{ }^{168}$. Kanaatimizce, öldürmek amacıyla ateş edip, fakat yaraladığı mağduru hastaneye kaldırarak kurtaran fail ile mağdura zehir içirdikten sonra panzehir vererek veya doktor çağırarak mağduru kurtaran failin durumu aynıdır. Çünkü her iki durumda da icra hareketleri tamamlandıktan sonra fail neticenin gerçekleşmesini kendi çabalarıyla önlemiş olmaktadır. Dolayısıyla bu iki örnekte de gönüllü vazgeçmeden değil etkin pişmanlıktan söz etmek gerekir.

İkinci görüşe göre ise, icra hareketleri tamamlandıktan sonra, yani tam teşebbüs aşamasında gönüllü vazgeçme hiçbir şekilde mümkün değildir ${ }^{169}$. Rarog, birinci görüşün 1960 tarihli RSFSCCK'nın yürürlükte olduğu dönemde geçerli olabileceğini; buna karşl1ık 1996 tarihli RFCK'nın açı hükmü nedeniyle bu görüşün artık savunulamayacağını ifade etmektedir. Çünkü 1996 tarihli RFCK'nın 61. maddesinde "suçun işlenmesinden hemen sonra mağdura tıbbi veya başka şekilde yardımda bulunma" cezayı hafifletici neden olarak düzenlenmiştir. Yani kanuna göre, failin neticenin ger-

\footnotetext{
163 Naumov, s. 314; Solopanov, s. 95.

164 Revin, s. 218.

165 İvanov, s. 254; Kriger/Kuznesova/Tkaçevkiy (Ed.), s. 172; Grişaev/Zdravomıslov, s. 214.

166 Naumov, s. 314; Durmanov, s. 202.

167 Naumov, s. 314

168 Durmanov, s. 202.

169 Belyaev/Şargorodskiy, s. 575; Zagorodnikov, s. 122-123; Rarog (Ed.), s. 196.
} 
çekleşmesini önlemesi durumu gönüllü vazgeçme değil, etkin pişmanlık kapsamında değerlendirilmektedir. Dolayısıyla gönüllü vazgeçme sadece hazırlık hareketleri ve eksik teşebbüs aşamasında mümkündür ${ }^{170}$.

Kanaatimizce 1960 tarihli RSFSCCK'nın yürürlükte olduğu dönemde, kanunun gönüllü vazgeçmeyi tanımlamaması nedeniyle birinci görüşün savunulması düşünülebilirdi. Fakat 1996 tarihli RFCK'nın gönüllü vazgeçmeyi açıkça tanımlaması nedeniyle ikinci görüş daha isabetlidir. Çünkü RFCK'nın 31/1. maddesine göre, "suça hazırlı hareketlerinin veya doğrudan doğruya suçun işlenmesine yönelmiş hareketlerin durdurulması", gönüllü vazgeçme sayılmaktadır. İcra hareketlerinin tamamlanmasından sonra, bitmiş olan hareket durdurulamayacağına göre, tam teşebbüs aşamasında, yani icra hareketleri tamamlandıktan sonra gönüllü vazgeçme mümkün değildir.

Rusya Federasyonu Yüksek Mahkemesi bazı kararlarında tam teşebbüs aşamasında gönüllü vazgeçmenin uygulanamayacağına karar verirken ${ }^{171}$, bazı kararlarında ise uygulanabileceğine karar vermiştir ${ }^{172}$.

$170 \quad \operatorname{Rarog}($ Ed.), s. 196.

171 Rusya Federasyonu Yüksek Mahkemesi'nin 22.12.1998 Tarih ve 78-098-38 No.lu Kararı: 'Sanık M'nin 'Çabuk öldür' talimatın yerine getirmekte olan diğer sanık L'nin mağdur B'yi çok sayıda yaraladı̆̆ olayda; L'nin 'yeter, artık yapamiyorum' diyerek hareketlerine son vermesi, B'nin ölmesi için gerekli olan tüm hareketler yapılmış olduğundan gönüllü vazgeçme olarak değerlendirilemez. Çünkü olayda, L, mağdurun başına beton parçasıyla vurmuş, onu metal telle boğmuştur. Daha sonra M, L'ye biçak vererek mağdurun bileklerini kesmesini söylemiş ve L denileni yapmıştır. Olayda mağdurun ölümünün gerçekleşmemesi, $M$ ve L'nin aşamadıklarl engellerden ötürü, yani iradeleri dışındaki nedenlerle meydana gelmiştir. Bu nedenle, mahkemenin sanıklar hakkında gönüllü vazgeçme hükümlerini uygulamaması ve M'nin ambulans çağırması durumunu cezayı hafifletici neden olarak dikkate alması doğrudur". (1999 Yılı 3 No.lu Yüksek Mahkeme Bülteni, http://www.supcourt.ru/files/11339/, E. T.: 03.05.2020); Rusya Federasyonu Yüksek Mahkemesi’nin 09.06.2010 ve 35-010-010 No.lu Karar1: "Sanıklar Smirnov ve Abramov mağdur M'yi dövmüss, kafasına taş, şişe ve sopayla vurmuşlardır. Daha sonra M'yi çıplak, başından ağır yaralı ve baygin olarak ussız yerde bir hendeğe atmiş, bir süre daha M'nin başına doğru taş attıktan sonra olay yerini terk etmişlerdir. Yapılan tıbbi müdahale sonucu mağdurun kurtulduğu bu olayda, sanıkların fiili doğrudan kastla insan öldürmeye tam teşebbüsün unsurların içermektedir. Bu koşullarda ve teşebbüsün bu aşamasında gönüllü vazgeçmeden söz edilemez. Bu nedenle mahkemenin sanıklar hakkında nitelikli insan öldürme (RFCK m.105/2-z (birden fazla kişi tarafindan)) suçuna teşebbüsten hüküm kurması doğrudur". (http://bazazakonov.ru/ doc/?ID=2383551, E. T.: 10.04.2011).

172 Rusya Federasyonu Yüksek Mahkemesi'nin 530P98 No.lu Karar1: “Karardan da görüldüğü gibi Y, öldürmek kastıyla bayan G'nin ve onun 11 yaşındaki oğlunun kafasına ve vücudunun diğer bölgelerine metal tavayla darbeler vurmuştur. Daha sonra $Y$, mağdurların baygın şekilde bulunduğu karavanın kapısını arkadan kilitlemiş ve karavanı 
Türk Ceza Kanunu'na bakıldığında ise gönüllü vazgeçmenin RFCK'dan farklı şekilde düzenlenmiş olduğu görülmektedir. TCK'nın 36/1. maddesine göre; "Fail, suçun icra hareketlerinden gönüllü vazgeçer veya kendi çabalarıyla suçun tamamlanmasını veya neticenin gerçekleşmesini önlerse, teşebbüsten dolayı cezalandırılmaz; fakat tamam olan kısım esasen bir suç oluşturduğu takdirde, sadece o suça ait ceza ile cezalandırılır". Örneğin öldürmek kastıyla yaraladığı kişinin ölmemesi için her türlü çabay1 gösteren kimse, ölüm sonucunu önlemiş ise, insan öldürmeye teşebbüsten dolayı değil, sadece kasten yaralama suçundan dolayı sorumlu olur ${ }^{173}$.

Görüldüğü gibi, yürürlükteki TCK'da sadece icra hareketlerinden vazgeçme durumunda değil, sonucun gerçekleşmesini önleme (etkin pişmanlık) durumunda da failin cezalandırılmayacağı kabul edilmiştir ${ }^{174}$. Başka bir ifadeyle, TCK, "gönüllü vazgeçme" ile "etkin pişmanlığı" aynı şey saymış ve aynı hükümlere tabi tutmuştur ${ }^{175}$. Kanaatimizce icra hareketleri bittikten sonra failin neticenin gerçekleşmesini önlemesi durumunda gönüllü vazgeçmenin değil, cezayı hafifletici neden olan etkin pişmanlık hükümlerinin uygulanması gerektiğini kabul eden RFCK'nın tutumu TCK'ya göre daha isabetlidir.

\section{Gönüllü Vazgeçmenin Sonucu}

Gönüllü vazgeçme, failin suça teşebbüs veya suça hazırlıktan dolayı cezalandırılmasını önler. Ancak gönüllü vazgeçme durumunda failin vazgeçme anına kadar yaptığ 1 hareketler bağımsız bir suçu oluşturuyorsa, fail o

ateşe vermişstir. Mağdure ateş ve duman nedeniyle hayatın kaybetmiş, onun oğlu ise yaralı olarak kurtulmuştur. İlk derece mahkemesinin Y'nin suçun işlendiği yere dönerek çocuğu ateşten kurtardı̆̆ını tespit etmesine rağmen, mağdurun (çocuğun) ölümünün sanığın elinde olmayan nedenlerle gerçekleşmediği sonucuna varması doğru değildir. Y'nin çocuğa karşı işlediği suç insan öldürme suçuna teşebbüs değil, kasten ağır yaralama suçunu oluşturur". (1999 Y1lı 3 No.lu Yüksek Mahkeme Bülteni, http://www.supcourt.ru/files/11339/, E. T.: 03.05.2020).

173 Toroslu, s. 268-269.

174 Madde gerekçesinde bu durum şu şekilde açıklanmıştır: "Gerek icra hareketleri aşamasında, gerekse icra hareketlerinin bitmesinden sonra, failin suçu tamamlamaktan gönüllü olarak vazgeçmesini teşvik etmek modern suç politikasının temel araçlarından biridir. 765 sayılı Türk Ceza Kanununda sadece icra hareketlerinin devamı aşamasında kabul edilen gönüllü vazgeçme, icra hareketlerinin bittiği ancak neticenin meydana gelmediği olaylar bakımından da öngörülmüştür. Böylece suçun icrası sürecindeki bütün aşamalarda gönüllü vazgeçme mümkün hale gelmektedir. Ancak icra hareketlerinin bitmesinden sonra gönüllü vazgeçmenin kabulü için, vazgeçenin suçun tamamlanmasını önlemek bakımından ciddi bir çaba göstermesi gerekmektedir".

175 Hafizoğulları/Özen, s. 321. 
suça ait ceza ile cezalandırılır (RFCK m.31/3). Örneğin insan öldürmek için ruhsatsız silah elde eden kişi, mağduru öldürmekten gönüllü vazgeçerse, insan öldürme suçuna teşebbüs veya hazırlıktan dolayı cezalandırılmaz, ancak ruhsatsız silah bulundurma suçundan (RFCK m.222) dolayı cezalandırılır ${ }^{176}$. Yine cinsel saldırıda bulunmak için mağdura hafif cebir uygulayan kişi, aniden gönüllü vazgeçerse, cinsel saldırı suçuna teşebbüsten dolayı cezalandırılmaz; ancak kasten hafif yaralama suçundan (RFCK m.115) dolayı cezalandır1lır ${ }^{177}$.

\section{Etkin Pişmanlık}

Rusya Federasyonu doktrininde etkin pişmanlık, suçun tamamlanmasından önceki ve sonraki etkin pişmanlık olmak üzere ikiye ayrılmaktadır ${ }^{178}$. RFCK'nın 61/1-k. maddesinde "suçun işlenmesinden hemen sonra mağdura tıbbi veya başka şekilde yardımda bulunma" genel cezayı hafifletici neden olarak düzenlenmiştir. Dolayısıyla RFCK'ya göre, failin icra hareketlerini tamamladıktan sonra, neticenin gerçekleşmesini önlemesi durumu, yani suç öncesi etkin pişmanlık genel cezayı hafifletici nedendir. Doktrinde ve uygulamada failin neticeyi önlemeye yönelik çabalarının başarısız olması durumu da RFCK'nın 61/1-k. kapsamında değerlendirilmektedir. Örneğin bir olayda $\mathrm{K}$, tartıştı̆̆ 1 'nin kafasına şişeyle vurup bayılttıktan sonra, pişmanlık duyarak mağdurun yarasına pansuman yapmış, ambulans çağırmış, ancak yine de M'nin ölmesini engelleyememiştir. Davaya bakan mahkeme etkin pişmanlık nedeniyle K'nın davranışlarını cezayı hafifletici neden olarak dikkate almıştır ${ }^{179}$. Ayrıca "suçun işlenmesinden hemen sonra mağdura tıbbi veya başka şekilde yardımda bulunma" sadece teşebbüse özgü bir hafifletici neden olmayıp, suç sonrası etkin pişmanlık hallerinde de uygulanabilmektedir. Örneğin failin kasten veya taksirle yaraladığı mağduru hastaneye kaldırması halinde sözü geçen hafifletici neden uygulanacaktır.

RFCK'da suç sonrası etkin pişmanlık da genel cezayı hafifletici neden olarak düzenlenmiştir. Kanunun 61/1-i. maddesine göre, "kendiliğinden teslim olma, suçun ve diğer suç ortaklarının ortaya çıkmasına, suçun işlenmesiyle elde edilen malın aranmasina aktif yardımda bulunma" cezayı hafifletici neden olarak dikkate alınmalıdır. Yine 61/1-k. maddeye göre, "suçun işlenmesinden hemen sonra mağdura tıbbi veya başka şekilde yardımda

\footnotetext{
176 Vetrov, s. 200.

177 Rarog (Ed.), s. 193

178 Durmanov, s. 207.

179 Bkz. Revin, s. 219.
} 
bulunma, suçtan doğan maddi ve manevi zararın gönüllü olarak tazmin edilmesi ve mă̆gurun uğradı̆g zararı gidermeye yönelik diğer hareketler" cezayı hafifletici nedendir. TCK'nın genel hükümlerinde ise buna benzer bir hüküm bulunmamaktadır. Ancak bu durumlar TCK 62. maddesinde düzenlenen "takdiri indirim nedenleri" kapsamında değerlendirilebiliir ${ }^{180}$.

RFCK'da suç sonrası etkin pişmanlığın cezayı tamamen ortadan kaldırdığı haller de vardır. "Etkin pişmanllk nedeniyle ceza vermekten vazgeçme" başlıklı RFCK'nın 75/1. maddesine göre; "İlk defa hafif veya orta dereceli suç işleyen kişi, suçun işlenmesinden sonra kendiliğinden teslim olmuş, suçun soruşturulmasına ve ortaya çıkmasına yardım etmiş, tazmin etme veya başka şekilde suçtan doğan zararl gidermiş ve etkin pişmanlı nedeniyle sosyal tehlikeli olmaktan çıkmışsa ceza vermekten vazgeçilebilir". TCK'nın genel hükümlerinde ise buna benzer bir hüküm bulunmamaktadır.

Bunun yanında RFCK'nın özel kısmında, suç sonrası etkin pişmanlık, bazı suçlarda $\left(\mathrm{m} .126^{181}, \mathrm{~m} .205^{182}, \mathrm{~m} .206^{183}\right.$ gibi) cezayı ortadan kaldıran neden olarak düzenlenmiş̧ir. Buna benzer bir şekilde suç sonrası etkin pişmanlık, TCK'nın özel kısmında da bazı suçlar bakımından kabul edilmiştir. Ancak RFCK'dan farklı olarak, TCK'daki suç sonrası etkin pişmanlık halleri, her zaman cezayı ortadan kaldırmamaktadır. TCK'nın özel kısmında belli suçlar bakımından kabul edilen suç sonrası etkin pişmanlık, bazı suçlarda cezayı ortadan kaldıran (m.93/1, m.254 gibi) nedenken, bazı suçlarda ise sadece cezayı hafifletici (m.168, m.110, m.248 gibi) nedendir.

180 “Takdiri indirim nedenleri” başlıklı TCK'nın 62. maddesine göre; “(1) Fail yararına cezayı hafifletecek takdiri nedenlerin varlı̆̆ hâlinde, ăğrlaştırlmış müebbet hapis cezast yerine, müebbet hapis; müebbet hapis cezasl yerine, yirmibes yll hapis cezasl verilir. Diğer cezaların altıda birine kadart indirilir. 2) Takdiri indirim nedeni olarak, failin geçmişi, sosyal ilişkileri, fiilden sonraki ve yargılama sürecindeki davranışları, cezanin failin geleceği üzerindeki olası etkileri gibi hususlar göz önünde bulundurulabilir. Takdiri indirim nedenleri kararda gösterilir".

181 RFCK'nın insan kaçırma suçunu düzenleyen 126. maddesinin ek notuna (son fikrasına) göre; "Kaçırılan kişiyi gönüllü olarak serbest birakan kişi, hareketleri başka bir suçu oluşturmuyor ise ceza sorumluluğu taşımaz".

182 RFCK'nın terör eylemi suçunu düzenleyen 205. maddesinin ek notuna (son fikrasına) göre; "Terör eylemine hazırlı fiiline katılan kişi, adli makamlara zamanında haber vermek suretiyle veya başka bir yöntemle terör eyleminin gerçekleşmesini önlerse, hareketleri başka bir suçu oluşturmuyor ise ceza sorumluluğu taşımaz".

183 RFCK'nın insan rehin alma suçunu düzenleyen 206. maddesinin ek notuna (son fikrasina) göre; "Gönüllü veya devlet organlarının talebi üzerine rehineyi serbest birakan kişi, hareketleri başka bir suçu oluşturmuyor ise ceza sorumluluğu taşımaz". 


\section{SONUÇ}

Suça teşebbüsün cezalandırılma nedeni konusunda objektif teoriyi esas alan Türk Ceza Kanunu'nun aksine, Rusya Federasyonu Ceza Kanunu'nda suça teşebbüsün cezalandırılma nedeni konusunda sübjektif teori esas alınmıştır. Rusya Federasyonu Ceza Kanunu'nda sadece suça teşebbüs değil, ağır ve nitelikli ağır suçlar bakımından hazırlık hareketleri de cezalandırılmaktadır. Kanaatimizce modern ceza kanunlarında kural olarak cezaland1rılmayan hazırlık hareketlerine Rusya Federasyonu Ceza Kanunu'nda ceza sorumluluğunun öngörülmüş olması isabetli olmamıştır.

Rusya Federasyonu ceza hukukunda suça teşebbüsün sadece doğrudan kastla işlenen suçlar yönünden mümkün olabileceği, olası kastla işlenen suçlara ise teşebbüsün mümkün olmadığ1 konusunda uygulamada ve doktrinde görüş birliği bulunmaktadır. Türk ceza hukukunda ise bu konu tartışmalı olup, bizim de katıldığımız doktrindeki baskın görüş olası kastla işlenen suçlara teşebbüsün mümkün olmadığı yönündedir.

Rusya Federasyonu Ceza Kanunu'nda ve doktrinde, icra hareketlerinin başlangıcının tespiti konusunda "objektif teori” kabul edilmiştir. Çünkü Kanunda teşebbüs için "doğrudan doğruya icraya başlama”nın gerekeceği ifade edilmiştir. İcra hareketlerinin ne zaman bitmiş sayılacağı konusunda ise doktrindeki baskın görüş sübjektif niteliktedir.

Rusya Federasyonu ceza hukukunda işlenemez suç (elverişsiz teşebbüs) halleri de cezalandırılmaktadır. Örneğin öldürmek amacıyla bir kimseye zehir zannederek tebeşir tozu vermek veya canlı zannederek cesede ateş etmek fiilleri teşebbüs hükümlerine göre cezalandırılmaktadır. Kanaatimizce, Türk ceza hukukunda olduğu gibi, Rusya Federasyonu ceza hukukunda da işlenemez suç hallerinde failin cezalandırılmaması gerekmektedir. Çünkü işlenemez suç hallerinde, hukuki konu doğrudan ve somut bir tehlikeye uğramış değildir ve dolayısıyla bu durumlarda doğrudan doğruya suçun icrasına başlandığından söz edilemez.

Rusya Federasyonu ceza hukukunda işlenemez suç halleri cezalandırılmakla birlikte; beddua, lanetleme, ölüm büyüsü yapma gibi sosyal açıdan tehlikeli olmayan hareketler, RFCK'nın 14/2. maddesi kapsamında değerlendirilmekte ve cezalandirılmamaktadir.

Rusya Federasyonu Ceza Kanunu'nda gönüllü vazgeçme, "suça hazırlık hareketlerinin veya doğrudan doğruya suçun işlenmesine yönelmiş hareketlerin durdurulması" şeklinde düzenlenmiştir. Doktrinde ve uygulamada icra hareketlerinin tamamlanması durumunda gönüllü vazgeçme hükümlerinin uygulanıp uygulanmayacağı konusunda görüş birliği bulunmamaktadır. 
Bir görüş, icra hareketleri tamamlandıktan sonra gönüllü vazgeçmenin hiçbir şekilde uygulanamayacağını; diğer görüş ise istisnai durumlarda icra hareketleri tamamlandıktan sonra gönüllü vazgeçmenin uygulanabileceğini savunmaktadır. Bununla birlikte, mağduru öldürmek amacıyla ateş eden, fakat mermileri boşa giden failin vazgeçerek tekrar ateş etmemesi veya öldürmek amacıyla ateş edip yaraladığı mağduru failin pişmanlık duyarak hastaneye kaldırıp yaralı olarak kurtarması gibi durumlarda gönüllü vazgeçmenin uygulanmayacağı konusunda görüş birliği bulunmaktadır. Bu tür durumlar cezayı hafifletici etkin pişmanlık olarak kabul edilmektedir. Kanaatimizce gönüllü vazgeçmenin bu tür durumlarda uygulanmaması isabetlidir.

Rusya Federasyonu Ceza Kanunu'nda suç öncesi ve suç sonrası etkin pişmanlık halleri düzenlenmiştir. Suç öncesi etkin pişmanlık, genel cezayı hafifletici neden olarak düzenlenmiştir. Suç sonrası etkin pişmanlık ise bazı durumlarda cezayı ortadan kaldıran neden olarak düzenlenmiştir. 


\section{KAYNAKÇA}

Alacakaptan, Uğur: İşlenemez Suç, Ankara 1968.

Aydın, Devrim: "Suça Teşebbüs", Ankara Üniversitesi Hukuk Fakültesi Dergisi, Cilt 55, Sayı 1, 2006, s. 85-113.

Belyaev, Nikolay/Şargorodskiy, Mihail: Kurs Sovetskogo Ugolovnogo Prava (Soyyet Ceza Hukuku Kursu), Obşaya Çast (Genel Kısım), Tom 1 (Cilt 1), Leningrad 1968, http://www.pravo.vuzlib.net/book z1030.html, E. T.: 18.12.2009.

Centel, Nur/Zafer, Hamide/Çakmut, Özlem: Türk Ceza Hukukuna Giriş, 10. Bas1, İstanbul 2017.

Demirbaş, Timur: Ceza Hukuku, Genel Hükümler, 10. Baskı, Ankara 2014.

Durmanov, Nikolay: Stadii Soverşeniya Prestupleniya (Suçun İşlenme Evreleri), Moskva 1955.

Dönmezer, Sulhi/Erman, Sahir: Nazari ve Tatbiki Ceza Hukuku, Genel Kisım, Cilt 1, İstanbul 1987.

Erem, Faruk/Danışman, Ahmet/Artuk, Mehmet Emin: Ümanist Doktrin Açısından Türk Ceza Hukuku, Genel Hükümler, Ankara 1997.

Grişaev, Pavel/Zdravomıslov, Boris: Sovetskoye Ugolovnoye Pravo (Sovyet Ceza Hukuku), Çast Obşaya (Genel Kısım), Moskva 1982.

Hafızoğulları, Zeki/Özen, Muharrem: Türk Ceza Hukuku, Genel Hükümler, 9. Bask1, Ankara 2016.

Hüseyinoğlu, Emin: "Suçun Biçimsel ve Maddi Anlayışı Açısından Rusya Federasyonu Ceza Hukukunda Suç Kavramı", Ankara Barosu Dergisi, Cilt 76, Say1 1, 2018, s. 120-146.

Hüseyinoğlu, Emin: "Rusya Federasyonu Ceza Hukukunda Suça İştirak”, Ankara Üniversitesi Hukuk Fakültesi Dergisi, Cilt 67, Sayı 4, 2019, s. 735-782.

Hüseyinoğlu, Emin: "Rusya Federasyonu Ceza Hukukunda Ölüm Cezası", Selçuk Üniversitesi Hukuk Fakültesi Dergisi, Cilt 28, Sayı 2, 2020, s. 427-444.

Hüseynov, Emin: Rusya Federasyonu Ceza Hukukunda Suça Teşebbüs, Ankara Üniversitesi, Sosyal Bilimler Enstitüsü, Doktora Tezi, Ankara 2011.

İgnatov, Aleksey/Krasikov, Yuriy (Ed.): Ugolovnoye Pravo Rosii (Rusya Ceza Hukuku), Obşaya Çast (Genel Kısım), Tom 1 (Cilt 1), Moskva 
2000, http://lib.maupfib.kg/wp-content/uploads/Ugolovnoe-pravoRossii_v-2t_T-1-Obshhaya-chast_Pod-red-Ignatova-Krasikova_2000639s.pdf, E. T.: 02.05.2020.

İçel, Kayıhan/Evik, A. Hakan: Ceza Hukuku, Genel Hükümler, 2. Kitap, 4. Bas1, İstanbul 2007.

İpekçioğlu, Pervin Aksoy: Türk Ceza Hukukunda Suça Teşebbüs, Ankara 2009.

İvanov, Nikita: Ugolovnoye Pravo Rosii (Rusya Ceza Hukuku), Obşaya i Osobennaya Çast (Genel ve Özel Kısım), Moskva 2003.

Korolkov, A. (Ed.): Kommentariy k Ugolovnomu Kodeksu Rossiyskoy Federasii (Rusya Federasyonu Ceza Kanunu'nun Şerhi), Moskva 2004.

Koca, Mahmut/Üzülmez, İlhan: Türk Ceza Hukuku, Genel Hükümler, 10. Bask1, Ankara 2017.

Kozaçenko, İvan/Neznamova, Zinaida (Ed.): Ugolovnoye Pravo (Ceza Hukuku), Obşaya Çast (Genel Kısım), Moskva 1997.

Kriger, German/Kurinov, Boris/Tkaçevskiy, Yuriy (Ed.): Sovetskoye Ugolovnoye Pravo (Sovyet Ceza Hukuku), Obşaya Çast (Genel Kısım), Moskva 1981.

Kriger, German/Kuznesova, Ninel/Tkaçevkiy, Yuriy (Ed.): Sovetskoye Ugolovnoye Pravo (Sovyet Ceza Hukuku), Obşaya Çast (Genel Kısım), Moskva 1988.

Kudryavsev, Vladimir/Luneev, Viktor/Naumov, Anatoliy (Ed.): Ugolovnoye Pravo Rosii (Rusya Ceza Hukuku), Obşaya Çast (Genel Kisim), Moskva 2006.

Kudryavsev, Vladimir/Naumov, Anatoliy (Ed.): Uçebnik Ugolovnogo Prava (Ceza Hukuku Ders Kitabı), Obşaya Çast (Genel Kısım), Moskva 1996.

Kurçenko, Vyaçeslav: "Problemı Kvalifikasii Prestupleniy v Usloviyah Faktiçeskoy Oşibki (Fiili Hata Şartlarında İşlenen Suçların Değerlendirilmesi Sorunu)", http://www.lawmix.ru/comm/3646, E. T.: 03.05.2020.

Kuznesova, Ninel: İzbrannıye Trudı (Seçilmiş Çalışmaları), Sankt-Peterburg 2003.

Kuznesova, Ninel/Tyajkova, İrina (Ed.): Kurs Ugolovnogo Prava (Ceza Hukuku Dersleri), Obşaya Çast (Genel Kısım), Uçeniya o Prestuplenii (Suç Hakkında), Tom 1 (Cilt 1), Moskva 2002. 
Magomedov, Asbeg: Ugolovnoye Pravo Rosii (Rusya Ceza Hukuku), Obşaya Çast (Genel Kısım), Moskva 1997.

Minkovskiy, Genrih/Magomedov, Asbeg/Revin, Valeriy: Ugolovnoye Pravo Rosii (Rusya Ceza Hukuku), Moskva 1998.

Moskova Bölge Mahkemesi'nin 05.10.2010 tarihli kararı, http://www.mosoblsud.ru/ss_detale.php?id=139185, E. T.: 01.03.2011.

Naumov, Anatoliy: (Tercüme: Qurbanov H.), Rusya Cinayet Hüququ, Ümumi Hisse, Bak1 1998.

Özgenç, İzzet: Türk Ceza Hukuku, Genel Hükümler, 11. Baskı, Ankara 2015.

Öztürk, Bahri/Erdem, Mustafa Ruhan: Uygulamalı Ceza Hukuku ve Güvenlik Tedbirleri Hukuku, Ankara 2015.

Piontkovskiy, Andrey: Kurs Sovetskogo Ugolovnogo Prava (Sovyet Ceza Hukuku Dersleri), Tom 2 (Cilt 2), Prestupleniye (Suç), Moskva 1970.

Rarog, Aleksey (Ed.): Ugolovnoye Pravo Rosii (Rusya Ceza Hukuku), Obşaya Çast (Genel Kısım), Moskva 2008.

Revin, Valeriy (Ed.): Ugolovnoye Pravo Rosii (Rusya Ceza Hukuku), Obşaya i Osobennaya Çast (Genel ve Özel Kısım), Moskva 2000.

Rusya Federasyonu Yüksek Mahkemesi'nin Resmi Web Sitesi, http://www.supcourt.ru, 03.05.2020.

Rusya Federasyonu Yüksek Mahkemesi'nin 02.08.2005 Tarih ve 66-o05-62 No.lu Karar1, http://pravosudie.biz/base1/data_sy/sudqsgbxv.htm, E. T.: 22.03.2011.

Rusya Federasyonu Yüksek Mahkemesi’nin 22.12.1998 Tarih ve 78-098-38 No.lu Karar1, http://bazazakonov.ru/doc/?ID=2383551, E. T.: 10.04.2011.

Sank-Peterspurg Şehir Mahkemesi’nin 17.03.1998 Tarihli Kararı, http://www.law.edu.ru/judicial/judicial.asp?judicialID=1124774, E. T.: 22.01.2010.

Semenderov, Firudin: Cinayet Hüququ, Ümumi Hisse, Bak1 2007.

Sereteli, Tinatin: "Nakazuyemost Prigotovleniya k Prestupleniyu po Sovetskomu Ugolovnomu Pravu (Sovyet Ceza Hukukuna Göre Suça Hazırlığın Cezalandırılabilirliği)", Sosialistiçeskaya Zakonnost, No:12, 1954, s. 10-15.

Smirnov, Andrey: "O Yuridiçeskoy Sile Postanavleniy Plenuma Verhovnogo Suda Rossiyskoy Federasii (Rusya Federasyonu Yüksek 
Mahkemesi Genel Kurul Kararlarının Hukuki Gücü Hakkında)", Oteçestvennaya Yurisprudensiya, No:12 (14), 2016, https://legalscience.ru/images/PDF/2016/14/o-yuridicheskoj-silepostanovlenij.pdf, E. T.: 02.05.2020.

Smolenskiy Bölge Mahkemesi'nin 2009 Tarihli Kararı, http://oblsud.sml.sudrf.ru/modules.php?name=docum_sud\&id=181, E. T.: 03.05.2020.

Solopanov, Yulian (Ed.): Sovetskoye Ugolovnoye Pravo (Sovyet Ceza Hukuku), Obşaya i Osobennaya Çast (Genel ve Özel Kısım), Moskva 1981.

Soyaslan, Doğan: Teşebbüs Suçu, Ankara 1994.

Sözüer, Adem: Suça Teşebbüs, İstanbul 1994.

SSCB Yüksek Mahkemesi'nin 19.09.1974 Tarihli Genel Kurul Kararı, http://projects.innovbusiness.ru/pravo/DocumShow_DocumID_33329.h tml, E. T.: 07.05.2011).

Sverdlovsk Bölge Mahkemesi'nin 25.02.2009 Tarih ve 22-1752/2009 No.lu Karar1, http://www.ekboblsud.ru/sudpr_det.php?srazd=6\&id=50\&page=2, E. T.: 03.05.2020.

Şargorodskiy, Mihail: Vina i Nakazaniye v Sovetskom Ugolovnom Prave (Sovyet Ceza Hukukunda Kusur ve Ceza), Moskva 1945.

Tagansev, Nikolay: Ugolovnoye Pravo (Ceza Hukuku), Obşaya Çast (Genel Kısım), Çast 1 (1. Bölüm), Po İzdaniyu 1902 Goda (1902 Y11 Baskısına Göre), 2003, http://www.allpravo.ru/library/doc101p0/ instrum105, E. T.: 02.01.2010.

Ter-Akopov, Arkadiy: Dobrovolnıy Otkaz ot Soverşeniya Prestupleniya (Suç İşlemekten Gönüllü Vazgeçme), Moskva 1982.

Tişkeviç, İvan: Prigotovleniye i Pokuşeniye po Sovetskomu Ugolovnomu Pravu (Sovyet Ceza Hukukuna Göre Hazırlık ve Teşebbüs), Moskva 1958.

Toroslu, Nevzat: Ceza Hukuku, Genel Kısım, 13. Baskı, Ankara 2009.

Tozman, Önder: Suça Teşebbüs, Ankara Üniversitesi, Sosyal Bilimler Enstitüsü, Doktora Tezi, Ankara 2008.

Traynin, Aron: "Ugolovnaya Otvetstvennost za Prigotovitelniye k Prestupleniyu Deystviya (Suça Hazırlık Hareketlerinden Dolayı Ceza Sorumluluğu)", Sosialistiçeskaya Zakonnost, No:12, 1953, s. 28-34. 
Veliyev, Samir: Cinayete Hazırlı̆ga ve Cinayet Etmeye Cehde Göre Mesuliyet Meseleleri, Bak1 2001.

Vetrov, Nikolay: Ugolovnoye Pravo (Ceza Hukuku), Obşaya Çast (Genel Kısım), Moskva 2002.

Vetrov, Nikolay/Lyapunov, Yuriy: Ugolovnoye Pravo (Ceza Hukuku), Çast Obşaya-Çast Osobennaya (Genel Kısım-Özel Kısım), Moskva 2007.

Yakimenko, Natalya: Osenka Maloznaçitelnosti Deaniya (Eylemin Az Önemliliğinin Değerlendirilmesi), Volgograd 1987, http://exjure.ru/law/news.php?newsid=54, E. T.: 03.05.2020.

Zagorodnikov, Nikolay: Sovetskoye Ugolovnoye Pravo (Sovyet Ceza Hukuku), Obşaya i Osobennaya Çast (Genel ve Özel Kısım), Moskva 1975.

Zdravomislov, Boris (Ed.): Ugolovnoye Pravo Rossiyskoy Federasii (Rusya Federasyonu Ceza Hukuku), Obşaya Çast (Genel Kısım), Moskva 1999. 